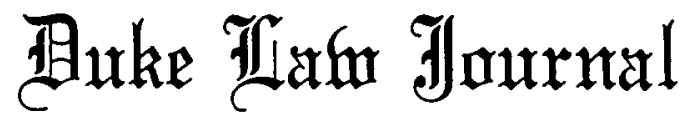

\section{APPROPRIATE LIMITS ON PARTICIPATION BY A FORMER AGENCY OFFICIAL IN MATTERS BEFORE AN AGENCY*}

\author{
THOMAS D. MORGAN**
}

I. INTRODUCTION................................. 2

II. The Historical Development of Post-Government EMPLOYMENT RESTRICTIONS.......................... 5

A. The Pre-1962 Legislation ....................... 5

B. Recognition of the Need for Reform ............... 6

C. The 1962 Legislation ........................... 9

D. Developments Between 1962 and 1978 ............. 11

* This Article is based on a report prepared for the Administrative Conference of the United States. The views expressed herein are personal opinions of the author and are not necessarily those of persons interviewed, the Administrative Conference of the United States, or the Duke Law Journal.

** Professor of Law, University of Illinois; A.B. 1962, Northwestern University, J.D. 1965, University of Chicago.

THE FOLLOWING CITATIONS WILL BE USED IN THIS ARTICLE:

ABA Code of Professional Responsibility (1978) [hereinafter cited as ABA CoDe];

COMMITTEE OF CONFERENCE, CONFERENCE REPORT, Ethics IN GOVERNMENT ACT of 1978, S. Doc. No. 127, 95th Cong., 2d Sess. (1978) [heremafter cited as S. Doc. No. 127];

Senate Comm. on Government Operations, I Study on Federal Regulation: The Regulatory Appointments Process, S. Doc. No. 25, 95th Cong., 1st Sess. (1977) [hereinafter cited as S. Doc. No. 25];

The Association of the Bar of the City of New York, Special Committee on the Federal Conflict of Laws, Conflict of INTEREST AND Federal SERvice (1960) [heremafter cited as BAR REPORT];

Comptroller General, General accounting Office, What Rules Should apply to Post-Federal Employment And How Should They Be Enforced?, Rep. No. B-103987, (1978) [hereinafter cited as GAO REPORT];

A. Kneier, Serving Two Masters: A Common Cause Study of Conflicts of IntereST IN THE Executive BRANCH (1976) [hereinafter cited as Common CaUSE Study];

Committee on Legal Ethics, D.C. Bar, Proposals for Amending the Disciplinary Rules of Canon 9 of the Code of Professional Responsibility, reported in Former Government Attorneys in Private Practice: Final Legal Ethics Committee Proposals for Comment, District LAW., Aug./Sept. 1978, at 53-57 [heremafter cited as D.C. Bar Proposals]. 
E. The Ethics Legislation of 1978 and 1979 ........... 18

F. The Events of 1979 ........................ 21

III. Problems in Establishing the Appropriate Limits on Private Activities After Government Service ...... 25

A. Difficulty Determining the Nature and Extent of the Revolving Door Phenomenon....................... 25

B. Issues To Be Addressed in Formulating Restrictions on Post-Employment Activity....................... 29

1. The Role of the Employee While in Government ... 29

2. The Lawyer's Role in Private Life .............. 30

3. General Procedural and Enforcement Issues ....... 32

IV. The Costs and Benefits of Regulating the Activities OF Former GovernMENT OfFicials................ 35

A. What Former Government Officials Bring to Private Employers ....................................... 35

B. Problems the "Revolving Door" is Thought to Present. 36

1. Protection of Client Confidences ................ 37

2. Switching Sides ........................... 38

3. Contacts or Clout ......................... 42

4. Unfair Advantage ........................... 43

5. Conflict of Loyalties ....................... 44

6. Imputed Knowledge of Partners and Associates.... 45

C. Costs Imposed By An Overly Restrictive Rule ........ 50

1. Problems for Government Recruitment ........... 51

2. Effects on Official Independence................ 53

3. The Effect on Personal Freedom of Employees and Those Who Employ Them ..................... 54

4. Dangers of Creating a Class of Professional Civil Servants ................................... 55

V. Proposed Approach to the Problem of Deciding When PARTICIPATION BY A Former AGENCY EMPLOYEe IS

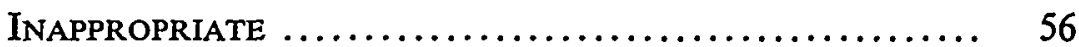

A. Some General Concerns........................ 56

B. The Analytical Questions Revisited ................ 56

1. The Role of the Employee While in Government ... 56

2. The Lawyer's Role in Private Life.............. 57

3. General Procedural and Enforcement Issues ...... 59

C. Specific Proposals............................. 62

\section{INTRODUCTION}

In a message to Congress early in his administration, President Carter asserted, "[a]11 too often officials have come into government for 
a short time and then left to accept a job in private industry, where one of their primary responsibilities is to handle contacts with the former employer."' He called for an end to this "misuse of influence acquired through public service."2

In its preadjournment rush, the ninety-fifth Congress granted the President's request for legislation by passing the Ethics in Government Act. ${ }^{3}$ For the ordmary federal employee, the changes were relatively minor: the existing one-year ban on appearing before one's agency with respect to any inatter within one's former "official responsibility" was extended to two years. ${ }^{4}$

However, the Act made signifieant changes regarding persons with "substantial decisionmaking authority," defined by the legislation as persons paid at level GS-17 or above.5 Such an official who left government after July 1, 1979, would be guilty of a felony if-even im the privacy of his or her office-he or she aided, counseled, advised, consulted, or assisted in representimg "any other person (except the Umited States)"6 in connection with a matter that was within his or her "official responsibility" within one year before he or she left the agency. ${ }^{7}$ Such an official would be barred from making any oral or written communication to the former agency on behalf of anyone other than the United States, even in matters arising after the official left office, mcluding a later rulemaking proceeding. ${ }^{8}$

This legislation was conservative in comparison to some of the other proposals pending at the time of its passage. The Bar Association for the District of Coluunbia, for example, was considering proposed amendinents to Disciplinary Rule 9-101 of its Code of Professional Responsibility that would have restrieted the activities of lawyers licensed

1. 13 WeekLy Comp. of PREs. DoC. 647, 649 (May 3, 1977).

2. Id.

3. Pub. L. No. 95-521, 92 Stat. 1824 (1978) (codified in scattered sectons of $2,5,18,26,28$ U.S.C.A. (West Supp. 1979)) (amended 1979).

4. 18 U.S.C.A. \& 207(b)(i) (West Supp. 1979) (amended 1979).

5. Id. $\& 207$ (d). Actually, four types of persons were placed in this category: (1) persons paid a sum equal to or greater than the Federal Executive Salary Schedule, set forth in 5 U.S.C. $\$ \$ 5311-5317$ (1976); (2) persons paid at or above the basic rate of GS-17, prescribed by 5 U.S.C. $\S 5332$ (1976); (c) active duty commissioned officers paid at level 0-7 or above as prescribed in 37 U.S.C. $\$ 201$ (1976); and (4) persons with "substantial decisionmaking authority" as defined by the Director of the Office of Government Ethics, a position created by Title IV of the legislation. Pub. L. No. 95-521, $\S \S 401-406,92$ Stat. 1824 (1978) (codified at 5 U.S.C.A. app. $\$ \S 401-405$ (West Supp. 1979)).

6. 18 U.S.C.A. \& 207(b) (West Supp. 1979) (amended 1979).

7. Id. $\S 207(\mathrm{~b})(3)$.

8. 18 U.S.C.A. $§ 207($ c) (West Supp. 1979). President Carter had imposed these requirements on his own appoimtees at the outset of his administration by requiring a letter of agreement to these terms. 35 CoNG. Q. $52-57$ (1977). 
in the District of Columbia even more severely than the federal statute. ${ }^{9}$ The Federal Trade Commission, in turn, had proposed to amend its own separate Rules of Procedure to forbid a former employee from participating in any proceeding in which his experience could give him an "unfair advantage." 10

Passage of the President's proposal should normally have preempted this other activity and resolved the issues, at least for the present. The new law, however, created problems of its own. In the eight months between passage of the legislation and its effective date, significant numbers of high-level administration officials suggested that they might resign in order to avoid the new strictures." Almost immediately after its passage, efforts to amend the law began. The Office of Government Ethics drafted regulations narrowly construing new section 207,12 and neinbers of both houses introduced bills "to clarify" and limit the new law. ${ }^{13}$ The President signed amendatory legislation in June 1979, less than two weeks before the provisions of the Ethics in Government Act were to have taken effect. ${ }^{14}$

Even with passage of these clarifying annendments, however, the question of the appropriate limits on activities of former government einployees remaims a problem of intense interest and practical concern to officials and agencies alike. On some crucially miportant issues-the attribution of a former government lawyer's disqualification to his or her current law partners, for example-the legislation is still totally silent, and conflictimg court decisions render the state of the law on these questions uncertain. ${ }^{15}$

This Article will discuss the controversy in its historical context, organize specific issues for systematic analysis, evaluate the various

9. One version of the proposed changes was publislied in DistRICT LAw., Winter 1977, at 46. The version pending at the time the legislation was considered appeared in DisTRICT LAW., Aug./Sept. 1978, at 44. The final version submitted for approval to the District of Columbia Court of Appeals in February 1979 is reported in Final Revolving Door Proposal Submitled 1o D.C. Court of Appeals, District LAW., Apr./May 1979, at 47-63. See notes 85-94 supra and accompanying text.

10. 16 C.F.R. $\$ 4.1$ (b) (1979). The proposed clianges were published in 43 Fed. Reg. 35,947 (1978). However, their adoption lias been deferred pending action of the District of Columbia Court of Appeals on the District of Columbia Bar proposal.

11. See A Federal Brain Drain, Newsweek, Mar. 5, 1979, at 51.

12. 5 C.F.R. $\$ 737$ (1979).

13. See, e.g., H.R. 21 19, 96th Cong., 1st Sess. (1979). See text accoinpanying note 122 infra.

14. Pub. L. No. 96-28, 93 Stat. 76 (1979) (to be codified at 18 U.S.C. $§ 207$ (b), (d)(1)-(2)). This was an amended version of S. 869, 96th Cong., 1st Sess. (1979), 125 CoNG. REC. S4241 (daily ed. Apr. 9, 1979). See text accompanying notes 127-31 infra.

15. Compare, e.g., Kesselhaut v. Umited States, 555 F.2d 791 (Ct. Cl. 1977) with Armstrong v. McAlpin, 606 F.2d 28 (2d Cir. 1979), rehearing en banc granted, No. 79-7042 (2d Cir. Dec. 12, 1979). 
criticisms of postemployment activity, and propose a simpler, more direct way of regulating the truly objectionable features of such activity.

\section{The Historical Development of Post-Government EMPLOYMENT RESTRICTIONS}

\section{A. The Pre-1962 Legislation.}

In the midnineteenth century, government was a far smaller enterprise than it is today. Much of its business, particularly in the period following the Civil War, consisted of paying "claims" against the government. These claims were often based on evidence that was hard to verify and were frequently processed and paid somewhat informally within the agency, subject only to audit and approval by the Comptroller of the Treasury. ${ }^{16}$ Fearful of collusion and fraud, Congress passed legislation designed to prevent active government officials from assisting private claimants in pressing their suits before government agencies, ${ }^{17}$ and in 1872 Congress extended the prohibition to former einployees. ${ }^{18}$ A rider to the post office appropriations bill provided:

[I]t shall not be lawful for any person . . . appointed an officer, clerk, or employee in any of the executive departments to act as counsel, attorney, or agent for prosecuting any claim against the United States which was pending in said Departments while he was said officer, clerk, or employee, nor in any manner, nor by any means, to aid in the prosecution of any such claim, within two years next after he shall have ceased to be such officer, clerk, or employee. ${ }^{19}$

This statute, codified as 5 U.S.C. $\$ 99$, remained unchanged for ninety years.

The language of this statute, however, created several problems. First, the statute related only to prosecuting claims, ${ }^{20}$ an ambiguous and arguably narrow proscription. Second, many government employees were considered exempt from the law because the Attorney General had taken the position that section 99 covered only employees of execu-

16. See, e.g., H. MANSField, THe Comptroller General 23-65 (1939).

17. Act of June 11, 1864, ch. 119, 13 Stat. 123 (codified at 18 U.S.C. $§ 281$ (1958)) (repealed 1962) (conipensated assistance); An Act to Prevent Frauds Upon the Treasury of the United States, ch. 18, \& 2, 10 Stat. 170 (1853) (codified at 18 U.S.C. § 283 (1958)) (repealed 1962) (uncompensated assistance). These laws forbade assistance by active officials regardless of whether they were compensated and regardless of whether the agency involved was the one for which they worked.

18. Post Office Appropriations Act, ch. 256, § 5, 17 Stat. 202 (1872) (codified at 5 U.S.C. $\S 99$ (1958)) (repealed 1962).

19. Id.

20. However, the terms had been construed to cover an appearance before Congress to obtain special legislation to pay an Indian upon whose land the United States had cut timber. Van Metre v. Nunn, 116 Minn. 444, 133 N.W. 1012 (1912). 
tive departinents, not those of independent agencies. ${ }^{21}$ In addition, the Attorney General later issued an opinion stating that even Army contracting officers were not considered employees of a "department" of government. ${ }^{22}$ Finally, the section did not provide for any penalty. A1though prosecution of a claim was not lawful, the penalty often imposed by courts was siniply denial of the former employee's fee for his claims collection service. ${ }^{23}$

These problems with section 99 led to the adoption of a second section on postemployment restrictions, section 284 of the Crimes and Criminal Procedure Act, ${ }^{24}$ which was incorporated into the revision of the federal criminal code in 1948:

Whoever, having been employed in an agency of the United States, including commissioned officers assigned to duty in such agency, within two years after the time when such employment or service has ceased, prosecutes or acts as counsel, attorney, or agent for prosecuting, any claims against the United States involving any subject matter directly connected with which such person was so employed or performed duty, shall be fined not inore than $\$ 10,000$ or imprisoned not more than one year, or both. 25

This section was an addition to, not a replacement for, the earlier statute. It substituted the term "agency" for the word "department," included military officers in its coverage, and imposed misdemeanor criminal penalties. At the same time, the coverage of the statute was significantly narrowed to prosecution of claims "involving any subject inatter directly connected with which such person was so employed or performed duty . . .."26

\section{B. Recognition of the Need for Reform.}

Attorneys are aniong those persons most affected by restrictions on employnient after government service. Not surprisingly, then, the American Bar Association Canons of Professional Ethics took a position on proper behavior of the former government lawyer. Canon 36 provided: "A lawyer, having once held public office or having been im the public eniploy, should not after his retirement accept employment in connection with any matter which he has investigated or passed

21. 25 OP. ATT'Y GEN. 6 (1903).

22. 31 OP. ATT'Y GEN. 471 (1919). Congress attempted to reverse this position with the Army Appropriations Act, ch. 8, 41 Stat. 104 (1919) (current version at 18 U.S.C.A. $\$ \$ 203-205$, 207 (1976 \& West Supp. 1979).

23. See, e.g., Van Metre v. Nunn, 116 Minn. 444, 133 N.W. 1012 (1912).

24. Ch. 139, $\$ 284,62$ Stat. 698 (1948) (codified at 18 U.S.C. $\$ 284$ (1958)) (repealed 1962).

25. $I d$.

26. $I d$. 
upon while in such office or employ."27 Further, and more generally, Canon 6 provided: "The obligation to represent the client witl undivided fidehity and not to divulge his secrets or confidences forbids also the subsequent acceptance of retamers or employment from others in inatters adversely affecting any imterest of the client witli respect to which confidence has been reposed." 28 The duty to preserve client confidences-presumably including government-client confidences-was established, in turn, by Canon $37 . .^{9}$

Two important cases in the 1950s helped catalyze the belief that the statutes and these Canons needed reexamination. In United States v. Bergson, ${ }^{30}$ decided in 1954, the defendant had been the former head of the Antitrust Division of the Department of Justice. Within two years after leaving office, Bergson wrote a letter to the Department seeking clearance for a particular corporate merger. The matter was clearly of the type he had handled while im office. He was prosecuted under section 284 of the then recently enacted Crimes and Criminal Procedure Act. ${ }^{31}$ The district court acquitted Bergson, however, on the ground that a request for premerger clearance was not a "claim agamst the United States" and thus did not violate the statute. The term "claim," said the court, "is limited to demands against the Government for money or for property." 32

For those who disapproved of Bergson's conduct, the reach of the statute was obviously inadequate. Even for otlers, the statute created an anomaly. The narrow construction of "claim" meant that a former Internal Revenue Service agent could help a taxpayer resist claimed taxes, for example, but could not lielp him seek a refund of taxes paid. ${ }^{33}$

An even inore celebratcd case was decided the next year. In United States v. Standard Oil Co. ${ }^{34}$ the defendant had sold crude oil to European firms at prices allegedly in excess of the maximum permitted by the Economic Cooperation Administration. Counsel for the defend-

27. aba Canons of Professional Ethics No. 36 (1937).

28. aba Canons of Professional Ethics No. 6 (1908).

29. ABA Canons of Professional Ethics No. 37 (1937). Canon 37 provided: "It is the duty of a lawyer to preserve his client's confidences. . . . A lawyer sliould not continue employment wlien he discovers that this obligation prevents the performance of his full duty to his former or to his new client."

30. 119 F. Supp. 459 (D.D.C. 1954).

31. Ch. 139, $\$ 284,62$ Stat. 698 (1948) (codified at 18 U.S.C. $\$ 284$ (I958)) (repealed 1962). See text accompanying note 25 supra.

32. $119 \mathrm{~F}$. Supp. at 465.

33. An even earlier recognition of the problems in the statutes was in McElwain \& Vorenberg, The Federal Conflict of Interest Statutes, 65 HARv. L. REv. 955 (1952).

34. 136 F. Supp. 345 (S.D.N.Y. 1955). 
ants included an attorney who had been employed in the Paris office of the Administration from 1949 to 1951. The government moved to have him disqualified pursuant to the Canons of Ethics, which had been adopted as rules of the court in the Southern District of New York. After a lengthy and specific factual analysis, the district court ruled that the former government attorney had not seen any of the documents relevant to the case, passed upon any of the issues in the case, or given legal advice in relation to any of the regulations involved. Thus, the court denied the inotion to disqualify. ${ }^{35}$

Several issues in the case sufficiently troubled District Judge Irving R. Kaufinan that he wrote an article in the Harvard Law Review ${ }^{36}$ about the case and the ambiguities that he saw in the existing law. He raised such questions as whether the statute required that the knowledge of other attorneys in the government office be imputed to an attorney, even though he had not seen any of the documents; whether the attorney's former client was the entire government, his former agency, his Paris office, or some other entity entirely; and when the "appearance of evil" would be such that an attorney should be disqualified even if there has been no actual abuse of confidential information. ${ }^{37}$

Judge Kaufman was not complaining that the reach of the Canons and statutes was too narrow. In fact, he felt that the "revolving door" practice should be "encouraged rather than discouraged." 38 His concern was with the aunbiguities faced by lawyers who were trying scrupulously to be ethical. Particularly troublesome was the problein created for "part-time" government employees such as consultants or members of boards and commissions. Did their public service disqualify thent and their law firms from all cases involving the government? Judge Kaufman asserted that "niany attorneys are turning down cases they should be free to take because of uncertainty as to the controlling ethical primciples." 39 He called attention to "the urgency of the problein" and urged the bar to "take ineasures to alleviate it."40

Publication of Judge Kaufman's commentary led to two further studies. In 1957, Chairman Celler of the House Judiciary Committee ordered a study of all the federal confiict of interest laws, including

35. Id. at 363-67.

36. Kaufman, The Former Government Attorney and the Canons of Professional Ethics, 70 HARV. L. REv. 657 (1957).

37. Id. 662-63.

38. Id. 668. There is a basis for arguing that Judge Kaufman's views may now have changed somewhat. See notes 70-73 infra and accompanying text.

39. Kaufman, supra note 36 , at 668 .

40. Id. 669. 
sections 99 and 284,41 and in 1958 the Association of the Bar of the City of New York created a ten-member committee with a professional staff headed by Professor Bayless Manning. The committee studied the problem for two years, and published its findings in a book that thoroughly analyzed the existing law and proposed draft legislation. ${ }^{42}$ The present federal restrictions on postemployment activity, mcluding their complexity and sophistication, can be traced in large part to this Association of the Bar Report.

\section{The 1962 Legislation.}

When the Kennedy admmistration took office in 1961, it appointed a three-member advisory panel to recommend changes in the federal conflict of interest laws.43 Within a few weeks, the panel presented proposals that were a simplified version of the Association of the Bar draft statute. Legislation was passed in the closing days of the eighty-seventh Congress. ${ }^{44}$

Section 207 of the new statute, the Bribery, Graft and Conflicts of Interest Act, ${ }^{45}$ reached all government employees, but it created a new category - that of "special Government employee"-to provide exceptions appropriate for certain kinds of consultants and other part-time employees ${ }^{46}$ Former employees were not forbidden from dealing with all subject inatters within their prior responsibility. The statute only prohibited subsequent activity with respect to defined "particular matters involving a specific party or parties." 47 Thus, for example, general policymaking activities of the employee, including participation in rulemaking activities, did not preclude his subsequent representation of a client in that area.

41. The resulting report was STAFF OF SUbCOMM. No. 5, House COMM. ON THE JudiciarY, 85th Cong., 2D Sess., Report on Federal Conflict of Interest Legislation (1958).

42. The balanced approach of the report is seen in its opening paragraph:

This book has two themes. The first is that ethical standards in the United States federal government must be beyond reproach. The second is that the federal government must be in a position to obtain the personnel and information it needs to meet the demands of the twentieth century. These themes are coequal. Neither may be safely subordmated to the other.

BAR REPORT 3.

43. The meinbers of the panel were Judge Calvert Magruder of the First Circuit, Dean Jefferson Fordhain of the University of Pennsylvania Law School, and Professor Bayless Manning.

44. Bribery, Graft and Conflicts of Interest Act, Pub. L. No. 87-849, 76 Stat. 1123 (1962) (codified at 18 U.S.C. $\$ \$ 201-218$ (1976)) (anmended 1977, 1978, 1979).

45. 18 U.S.C. $\$ 207$ (1976) (anended 1978, 1979).

46. The term, "special Government einployee," is defined in section 202(a) to mean (in addition to several specially defined cases) any person "employed . . . , with or without coinpensation, for not to exceed one hundred and thirty days during any period of three hundred and sixty-five consecutive days . . . ."Id. §202(a) (1976) (amended 1978).

47. Id. § 207(a), (b) (1976) (anended 1978, 1979). 
The legislation differed from the Bar Association's draft statute in several respects. The Association of the Bar proposal would have placed permanent limitations on the employee's activity im matters im which he had "participated" during his government employment. ${ }^{48}$ The concept of "participation" was substantially qualified in the statute to read "participated personally and substantially . . . through decision, approval, disapproval, recommendation, the rendering of advice, investigation or otherwise . . . ."49

The Bar Association had also proposed a two-year ban on activities concerning "transactions" that had been under the employee's "official responsibility" while working for the government. ${ }^{50}$ This was a direct reaction to the Standard Oil case. 51 The concept of "official responsibility" was defined in the proposal as "the direct administrative or operating authority . . . effectively to approve, disapprove, or otherwise direct Government action."52 The statute adopted this concept but set the ban at only one year. ${ }^{53}$ In addition, the statute was inore specific than the Bar Association draft in describing prohibited subsequent activity. The phrase "assist another person" in the Association of the Bar proposal was changed im the statute to "act as agent or attorney for anyone." 54 Coupled with the requirement of a "particular inatter," the prohibition apphied only to persons acting in a representative capacity in a judicial or an administrative proceeding. The language did not prohibit office counseling. As recommended by the Association of the Bar, section 208 expressly prohibited a current federal employee froin participating in any matter im which "any person or organization with whoin he is negotiating or has any arrangeinent concerning prospective employment has a financial interest." 55 That disqualification was, however, subject to waiver by the "official responsible for [the employee's] appointinent to his position . . . [upon a showing that the] interest is not so substantial as to be deemed likely to affect the integrity of the services which the government inay expect froin sucli officer or

48. BAR REPORT 292.

49. 18 U.S.C. $\$ 207$ (a) (1976) (amended 1978) (emphasis added).

50. BAR REPORT 292.

51. United States v. Standard Oil Co., 136 F. Supp. 345 (S.D.N.Y. 1955). See text accompanying notes 34-35 supra.

52. BAR REPORT 275 .

53. 18 U.S.C. $\$ 207$ (b) (1976) (amended 1978, 1979). The term "official responsibility" is defined in section 202(b) in accord with the Bar's definition.

54. Id. $\S 207$ (a), (b) (1976) (amended 1978, 1979). In addition, the 1962 law, for the first time, inade it clear that activities consistent with the government's interest, not just those opposed to it, were prohibited. The law covered any matter "in which the United States is a party or has a direct and substantial interest." Id.

55. Id. $\S 208($ a) (1976) (amended 1977). 
employee . . . ."56

In a major departure from the Association of the Bar proposal, section 207 failed to require that partnerships in which the former official was involved be disqualified. 57 The House bill had provided for imputed disqualification, but the Senate rejected that provision. The point was controversial, and the legislative history shows that Congress rationalized that the only people to whom the issue was of practical concern were attorneys. Attorneys had their own standards of legal ethics governing disqualification of law firms, Congress reasoned, and the issue should be resolved by those standards. ${ }^{58}$ The statute contained no provision for waiving the former employee's own disqualification, ${ }^{59}$ and as a result of the silence on disqualification of partnerships, there was also no reference to waiver of imputed disquahfication.

Finally, the statute upgraded the criminal sanctions to felony status, but failed to go further and adopt the Association of the Bar proposal to create civil and administrative penalties as well.60

\section{Developments Between 1962 and 1978.}

The "revolving door" between private life and government service was not a subject of significant attention in the years shortly after 1962 . President Johnson, for example, issued an important Executive Order

56. Id. $\S 208(\mathrm{~b})$.

57. Indeed the last sentence of section 207 read: "A partner of a present or former officer or employee... shall as such be subject to . . . [Section 207] only as expressly provided in subsection (c) of this section." Subsection "c" did not deal with the former employee; it dealt only with partners of present employees.

The Bar's proposed statute would have created a two-year ban on the partnership's assistance in inatters in which the former government employee "participated" during government employmeut; these were, it will be remembered, inatters for which the employee himself would have been permanently disqualified. No limitation was to be placed on the law firm's involvement in inatters within the "official responsibility" of the former government employee. BAR REPORT 292-93.

58. See S. REP. No. 2213, 87th Cong., 2d Sess. 13 (1962). This view is confirmed by the interpretative inemorandum of Attorney General Robert Kennedy, 28 Fed. Reg. 985, 988 (1963). See also Perkins, The New Federal Conflict-of-Interest Laws, 76 HARv. L. REv. 1113, 1159-62 (1963).

59. The Bar had proposed a narrowly drawn waiver procedure. In matters involving federal contracts, application could be inade to the head of the agency for which the former employee had worked to certify that the former employee has "special knowledge" or skills necessary to the performance of the contract. BAR REPORT 285-86.

60. In addition to proposing enforcement by criminal penalties, the Bar Committee proposed a civil damage remedy and an administrative remedy that would bar the former einployee from appearing before, or negotiating busimess with, the agency if a violation were proved. Id. 299-303. This "administrative remedy" reappeared in the 1978 amendments to section 207, and is now codified in 18 U.S.C.A. $\$ 207($ ) $)$ (West Supp. 1979). 
on Ethics in Government Services in $1965,{ }^{61}$ in which he did not even inention the subject. For many years, of course, critics of military spendimg had mamtained that the practice of recruiting Department of Defense personnel from companies that are defense contractors led to the perceived need for large defense budgets. ${ }^{62}$ These critics had also alleged that these companies might be receiving favored treatment fron 1 their former employees or fron1 persons wanting positions with these firms upon leaving the government. ${ }^{63}$ The only statutory response to these charges, however, was to require former high-level Defense Departnient and National Aeronautics and Space Administration officials to report any dealing they had with their former agencies during the first three years after their departure from the government. ${ }^{64}$ The substantive requirenients on such persons were the same as those that section 207 imposed on all other former officials.

Studies by Ralph Nader organizations in the late 1960s and early $1970 \mathrm{~s}^{65}$ apparently were the turning poimt in perceptions of the "revolving door" phenomenon. These reports helped popularize the view that regulation was going wrong, not because it had been misconceived im the first place but because the process had been "captured" by the regulated firms. ${ }^{66}$ One way to explaim the occurrence of this alleged capture was to point to the allegedly incestuous relationship between persons working for regulatory agencies and the firms for which they ultimately expected to work.

About the same time as the Nader studies, public-interest organizations-representimg groups formerly thought to lack representation in governmental decisionmaking processes ${ }^{67}$ - came to national promi-

61. Exec. Order No. 11,222, 3 C.F.R. 386 (1969). Indeed, by Exec. Order No. 11,451, reprinted in 5 U.S.C. $\$ 4103$ note (1976), President Johnson established a Commission on Personnel Intercliange designed to encourage employees of private firms to engage in temporary government service and government employees to work temporarily in private industry. See id.

62. E.g., W. PROXMIRe, Report From Wasteland: America's Military Industrial Complex (1970).

63. Id. $123-50$.

64. 42 U.S.C. $§ 2462$ (1976); 50 U.S.C. § 1436 (1976). Both restrictions were origimally adopted in 1969 as part of the respective agency authorization bills, H.R. 11271, 91 st Cong., lst Sess. (1969), and S. 2546, 91st Cong., 1st Sess. (1969).

65. E.g., The Closed Enterprise System (M. Green ed. 1971); E. Cox, R. Fellmeth \& J. Schulz, The Nader Report on the Federal Trade Commission (1969); R. Fellmeth, The INTERSTATE COMMERCE OMISSION (1970).

66. For many years, other econonnic historians have asserted that regulatory programs were never really imposed on unwilling industries. Instead, under this view, imdustries that had diffculty forming cartels sought nominal regulation that was, in fact, in their private interest. $E_{\text {.g. }}$, G. KolKo, The Triumph OF Conservatism (1963). This perception, lowever, was not widely accepted until Nader gave it a populist flair.

67. See, e.g., M. Green, The Other Government: The Unseen Power of Washington Lawyers (rev. ed. 1978); B. Weisbrod, J. HANDler, \& N. Komesar, Public INTERest LaW: 
nence. These organizations claimed that one reason their views had not been considered was that they were excluded from the revolving door process. That is, if all the decisionmakers came from industry and expected to return there, their decisions could not be expected to reflect the general public interest.

For lawyers, one key development was the American Bar Association's adoption of a new Code of Professional Responsibility in 1969. Disciplinary Rule 9-101(B) of that Code provides: "A lawyer shall not accept private employment in a matter in which he had substantial responsibility while he was a public employee."68 The related Ethical Consideration, EC 9-3, explams that "to accept employment [under these circumstances] would give the appearance of impropriety even if none exists." 69

No reported disciplinary cases were brought to enforce these provisions, but the provisions did provide a basis for the decision of the Second Circuit in General Motors Corp. v. City of New York. ${ }^{70}$ In that case, New York City wished to file a class action suit alleging that Gen-

AN Economic and Institutional. ANALysis (1978); Rabin, Lawyers for Social Change: Perspectives on Public Interest Law, 28 STAN. L. Rev. 207 (1976); Symposium, The Practice of Law in the Public Interest, 13 ARIz. L. Rev. 797 (I971); Note, The New Public Interest Lawyers, 79 YALE L.J. 1069 (1970).

68. ABA CoDE DR 9-10I(B). The term "matter" in this Disciplinary Rule was apparently meant to pick up the distinction made in Allied Realty of St. Paul, Inc. v. Exchange Nat'l Bank, 283 F. Supp. 464 (D. Minn. 1968), affd, 408 F.2d 1099 (8th Cir.), cert. denied, 396 U.S. 823 (1969), decided the preceding year. In that case, a young assistant United States attorney had "second chaired" a criminal trial in which it was alleged that the defendant had fraudulently purported to place a mortgage on a piece of property to get a loan for a national bank. After leaving the United States attorney's office, the lawyer filed a civil fraud suit on behalf of the bank against the former criminal defendant. This later suit was not contrary to the interest of the government; indeed it furthered the deterrent and remedial policy of the criminal law. Yet a motion to disqualify the lawyer was granted. General knowledge about the operation of the government and even the pohicies apphed in a particular office would not constitute the basis for disqualification, the court reasoned, but when the specific subject matter of the private suit was the saine as that on which the lawyer worked as a pubhc einployee, disqualification had to be ordered. No confidences in the normal scnse were compromised by this representation, but the identity of the subject matter was decisive.

Note that the ABA ban, like section 207(a), is permanent. However, the ABA Code apphes to all public lawyers equally and does not establish separate rules for part-time employees, former military officers, and the like. Further, the intensity of the relationship to the case is defined as "substantial responsibihty." Presumably that is something more than "official responsibility," but less than "personal and substantial" participation, although not even the footnotes to the Code indicate why this particular standard was chosen. Fimally, while section 207 limits only certain kinds of government contacts, the ABA standard prohibits giving private counsel and acting as an attorney in all forums, presumably including Congress, as long as the "matter" is the same.

69. ABA CoDE EC 9-3. Under the ABA Code, a Disciplinary Rule is "mandatory" and a violation of it will subject the offender to professional discipline. An Ethical Consideration is "aspirational" and often provides a form of legislative history.

70. 501 F.2d 639 (2d Cir. 1974). 
eral Motors liad monopolized or attempted to monopolize the national market for city buses. The City hired a private lawyer, George J. Reycraft, to represent it on a contingent fee basis. When first approached, Mr. Reycraft informed the city corporation counsel tliat he had worked in the Antitrust Division of the Department of Justice on an investigation of the same issue. Altliougl he had not been "in active charge of the case," 71 lie liad participated substantially in preparing a complaint against General Motors and had signed the Antitrust Division complaint in 1956. The Justice Department formally advised Mr. Reycraft that section 207 did not apply to his case because the government was neitler involved in nor affected by the results of the private suit.

After Mr. Reycraft filed a coinplaint on behalf of the City im October 1972, the primary issue became the effect of Disciplinary Rule 9101(B) on the propriety of Reycraft's representation. The district court ruled that the 1956 Antitrust Division case and the 1972 private suit were not the same "matter," but the Second Circuit disagreed. In an opinion by the same Judge Kaufman who had expressed his concern about the overbreadtli of the Canons of Ethics in the Harvard Law Review nineteen years earlier, ${ }^{72}$ the court reasoned that simce the overt acts alleged in the private complaint liad been lifted directly from the Justice Department complaimt, the "appearance of impropriety" was present and that Mr. Reycraft inust therefore be disquahified. ${ }^{73}$

In this period of growing liostility toward the revolving door phenomenon, the attitudes expressed by American Bar Association Formal Opinion No. $342^{74}$ in 1975 provided a striking contrast. At the time of the adoption of the American Bar Association Code in 1969, its principle for imputing disqualification of one lawyer to his entire law firm was very narrow. Disciplinary Rule 5-105(D) then provided: "If a lawyer is required to decline employment or to withdraw from employment under DR 5-105, no partner or associate, of his firm may accept or contimue such employment."75 The key was the reference to Disciplinary Rule 5-105, which prohibited simultaneously representing two or more clients witl differing interests, but which did not prohibit tak-

71. Id. at 642 (quoting affidavit of Mr. Reycraft).

72. See notes $36-40$ supra and accompanying text.

73. The court cited ABA Comm. on Professional Ethics, Opinions, No. 37 (1931) for the idea that the rule was to prevent the charge that an einployee had acted in "the hope of being later employed privately to uphold or upset what he had done." $501 \mathrm{~F} .2 \mathrm{~d}$ at 649 (emphasis in original). Citing his Harvard Law Review article, Judge Kaufman concluded that "what crcates an appearance of evil . . . is largely a question of current ethical-legal mores." Id. (citing Kaufman, supra note 36 , at 660 ).

74. ABA Comm. on Professional Ethics, Opinions, No. 342 (1975), reprinted in 62 A.B.A.J. 517 (1976).

75. ABA Code of Professional Responsibility DR 5-105(D) (1969). 
ing a case contrary to the interest of a former client. ${ }^{76}$ In 1975 , however, Disciplinary Rule 5-105(D) was amended by substituting the words "disciplinary rule" for "DR 5-105." The effect of this amendment is that whenever a lawyer is disqualified for any reason under the American Bar Association Code, every meinber of his or her law firm is also disqualified. This rule apparently extends, therefore, to disqualifications required of former government lawyers under Disciplinary Rule 9-101(B).

The explanation of the extension, set forth in Formal Opinion No. 342 of the American Bar Association Committee on Professional Ethics, however, indicates that constraining the revolving door phenomenon was not what the Committee had in mind. After considermg the anbiguity and intent of Disciplinary Rule 9-101(B), the Committee reasoned that an "inflexible apphication of DR 5-105(D) would actually thwart the policy considerations underlying DR 9-101(B)."77 According to the Committee, the phrase "substantial responsibility" was used in Disciplinary Rule 9-101(B)

to inhibit government recruitment as little as possible and enhance the opportunity for all litigants to obtain competent counsel of their own choosing, particularly in specialized areas. An inflexible extension of disqualification throughout an entire firm would thwart those purposes. So long as the individual lawyer is held to be disqualified and is screened from any direct or indirect participation in the matter, the problen of his switching sides is not present . . . ${ }^{78}$

The opinion concluded that the purposes of Disciplinary Rule 9-101(B) can be accomplished by requiring disqualification only when the disqualified lawyer "has not been screened, to the satisfaction of the government agency concerned, from participation in the work and compensation of the firm on any matter over which as a public einployee he had substantial responsibility.' 79 Further, the Committee reasoned that since a private chent can waive disqualification of a lawyer pursuant to Disciplinary Rule 5-105(C), it would be "unthinkable" not to permit the government to waive the disqualification of the opposing party's attorney whenever it is satisfied that the "screening measures will effectively isolate the individual lawyer from participating in the particular natter and sharing in the fees attributable to it, and that there is no appearance of significant impropriety affecting the

76. The prohibition against taking a case contrary to the interest of a former chent is derived by inference from Canon 4, which requires preservation of the confidences and secrets of a client.

77. ABA OpINIONs, No. 342, supra note 74, at 10, reprinted in 62 A.B.A.J. 517,520 (1976).

78. Id. 11,62 A.B.A.J. 521.

79. Id. 
interest of the government . . . ."80

At the tinie of this opinion, however, the nation had just come through the events of Watergate. Concern about ethics and public morahty was high, and the American Bar Association's concern about preserving the interchange of persons between public and private life was not universal. Indeed, Common Cause conducted a widely publicized study in 1976,81 and found that "numerous public employees leave government to go to work for private interests with which they had direct dealings." 82 It expressed concern about government employees' "bias toward companies or industries in which future employment is anticipated" and the ability of former officials to have "special access and influence" in their agencies. ${ }^{83}$ Under the Common Cause proposal, agency officials at level GS-15 or above would have been required to sign a contract proinising that for two years after leaving the government, they would not accept employment with any company that was party to a "specific ageney or proceeding" or "affected by a policy proceeding" in which the employee participated, and promismg never to represent any company before the former agency. ${ }^{84}$

Meanwhile, the Ethics Committee of the District of Columbia Bar had before it Inquiry 19, a request for guidance from two partners, $A \&$ $B$, who had been retained to negotiate a "follow-on" contract between a client and the lawyers' former agency. $B$ had been involved in discussions about the the original contract while still at the agency; $A$ had been administrative head of the agency. The Ethics Committee issued a draft opinion that $B$ was disqualified because of his personal participation in the original contractimg process and that his disqualification liad to be imputed to $A .^{85}$ However, the storm of protests over this draft caused the Ethics Committee to refer the inatter to a subcommittee to propose possible revisions to the District of Colunbia version of Disciplinary Rule 9-101 itself. The subcommittee's controversial report ${ }^{86}$ proposed tight restrictions on the postgovernment practice of

80. Id 12. The Committee on Professional and Judicial Ethics of the Association of the Bar of the City of New York reached the same conclusions in its Opinion No. 889, reprinted in 31 REC. 552, 566 (1976). The philosophy of both opinions was adopted by the Court of Claims in Kesselhaut v. United States, 555 F.2d 791 (Ct. Cl. 1977), but rejected in Armstrong v. McAlpin, 606 F.2d 28 (2d Cir. 1979), rehearing en banc granted, No. 79-7042 (2d Cir. Dec. 12, 1979).

81. Common Cause Study.

82. Id. $i$.

83. Id iii.

84. Id $64,71-72$.

85. The exposure draft was published in District LAw., Fall 1976, at 39.

86. The text of the original proposal is reported in DisTrict LAw., Winter 1977, at 46. A debate on the then new proposal between Lloyd Cutler and Monroe Freedman may be found in 63 A.B.A.J. 724 (1977). 
lawyers.

First, the proposed District of Columbia Bar rules would have prohibited a lawyer from counseling or representing a client on any subject, if that client was involved in any matter in which the lawyer participated personally and substantially within one year prior to leaving the government. Thus, if a Securities and Exchange Commission lawyer had dealt with a company on a securities matter while in government, he or she would be barred from assisting that company in any way, even, for example, on tax questions. An alternative proposal would have prohibited a lawyer from being hired by any law firm that had represented any client in a matter in which the attorney had participated personally and substantially within one year prior to his or her leaving government. ${ }^{87}$

Second, the District of Columbia Bar proposals would have prohibited a lawyer for one year after leaving government from counseling or representing a client

with respect to the validity, interpretation, scope, application or proposed inodification or recission of any provision of a rule or regulation of general applicability, if the lawyer previously participated personally and substantially as a public officer or employee, within one year before leaving public office or employment, in the drafting of or decision to propose or adopt such proposed or effective provision. ${ }^{88}$

Thus, for one year the lawyer most knowledgeable about the meaning of an agency rule, for example, would be forbidden from providing anyone with the benefit of his or her expertise.

Third, unlike the federal statute, the District of Columbia Bar proposal dealt directly with the question of imputed disqualification. It provided that if one lawyer of the firm was disqualified, then all were disqualified, unless a detailed procedure for waiver was followed. ${ }^{89}$ Waiver could be obtained, but only from the "lawyer or other official who [had] principal operational responsibility for the matter for the public agency or department upon determination by that official that the waiver [was] not inconsistent with the public interest."90 In order to get such a waiver, the lawyer's firm, at minimum, would have had to provide an affidavit that the lawyer would not "participate in the matter in any way, directly or indirectly, ... [ [and would not] share, di-

87. D.C. Bar Proposals 53-54 (proposed new DR 9-101(D)). See Memorandum from William H. Allen, Chairman, Legal Ethics Committee, to the Board of Governors of the D.C. Bar (July 3, 1978), reported in District LAW., Aug./Sept. 1978, at 44-53.

88. D.C. Bar Proposals 54 (proposed DR 9-101(E)).

89. Id. 54-5S (proposed DR 9-102(B)).

90. Id. 55 (proposed DR 9-102(B)(1)(a)). 
rectly or indirectly, in any fees of the inatter."91 Further, each of the firm's private lawyers working on the matter would be required to provide his or her own affidavit attesting that "he or she [would] not communicate about the matter directly or indirectly with the disqualified lawyer, and . . . that the chent or chients [had] been so informed."92 The waiver would have to be in writing and state "clearly the basis for the decision,"93 after which the waiver would immediately be inade public. The original version of the proposal even required that the decision of the official to grant the waiver be reviewed in turn by a judge or other "independent official." 94

\section{E. The Ethics Legislation of 1978 and 1979.}

President Carter reached office in the wake of-and partly as a result of-public concern about personal inorahty im government. It is not surprising, therefore, that the ninety-fifth Congress' H.R. ${ }^{95}$ was an "ethics" bill. The groundwork for such legislation had been laid earlier. In the ninety-fourth Congress, Senator Ribicoff and the Government Operations Committee had conducted an extensive study of the process of government regulation. ${ }^{96}$ The first volume of that study considered appointments to the regulatory agencies and contamed an extended, careful examination of existing conflict-of-interest legislation. ${ }^{97}$ The inajor focus of H.R. 1 and its earher drafts, however, was financial disclosure. ${ }^{98}$ Such disclosure was one of the chief concerns coming out of the Watergate scandal, although the relationship between the two is unclear. The proposals required extensive financial disclosure by meinbers of Congress and federal judges, as well as executive branch officials and certain employees of imdependent agencies. Although inost of the bills contained provisions to amend section 207, these provisions received relatively little attention from congressmen and sena-

91. Id. (proposed DR 9-102(B)(1)(b)(1)).

92. Id. (proposed DR 9-102(B)(1)(b)(2)).

93. Id. (proposed DR 9-102(B)(1)(a)).

94. Id. 55,57 n.4. The final proposals submitted for approval of the District of Columbia Court of Appeals are reported in Districr LAW., Apr./May 1979, at 47.

95. H.R. 1, 95th Cong., 1st Sess. (1977), reprinted in Hearings on H.R. I, H.R. 9, H.R. 6954 and Companion Bills, Financial Disclosure Act, Before the Subcomm. on Administrative Law and Government Relations of the House Comm. on the Judiciary, 95th Cong., 1st Sess. 3 (1977).

96. S. Doc. No. 25.

97. Id. 39-91.

98. In the Senate, the key bill was Senator Ribicoff's Public Officials Integrity Act, S. 555, 95th Cong., 1st Sess. (1977). That bill provided for financial disclosure, but it had additional provisions. One title established a congressional legal counsel to represent Congress in court; another established the machinery for appointing a special prosecutor to deal with executive branch misbehavior. Still another provision established an Office of Government Ethics to monitor and regulate the behavior of government officials. 
tors or even from most congressional staffs. The Senate bill, S. 555,99 passed the Senate by a wide margin in June $1977,{ }^{100}$ and what real debate arose over the legislation occurred in the House and later in the conference committee.

Major opposition to the proposed changes caine primarily from two sources. First, the House Armed Services Committee echoed the concern of the Defense Department that stringent restrictions on the postemployment activities of government personnel would inhibit persons from providing valuable advice to the Department. The committee expressed particular concern about "special government employees" such as consultants and other experts. It posed the example of a nuclear scientist who might consult with the Defense Department on complex technical questions and who also does extensive consulting for (or even is employed by) a defense contractor. Committee meinbers argued that such persons are often unique national resources and that free access to their advice, undiscouraged by limitations on their later employability, is essential. ${ }^{101}$

Second, the Securities and Exchange Commission took great interest in the legislation, fearing its effect on recruiting. The Securities and Exchange Commission pointed out that many young lawyers come to work for the Commission expressly to gain experience in the securities business. After leaving, if these lawyers are to practice securities law at all, they must practice before the Commission. The Commission is not the only agency with this problem, of course, but it was by far the most vocal agency with respect to the bill. 102

Despite this opposition, H.R. $1^{103}$ passed the House shortly before adjournment. ${ }^{104}$ After a short but compromising conference, an amended version of S. $555^{105}$ passed both houses by a large margin. ${ }^{106}$ As one individual recalled, "The President wanted it. There was no

99. 95 Cong., Ist Sess. (1977).

100. The vote was 74 to 5. 123 Cong. REC. $\$ 10,774$ (daily ed. June 27, 1977). For the basic legislative history, see [1978] U.S. CODE CONG. \& AD. NEws 4216-4397.

101. House Comm. ON ARmed Services, Ethics in Government ACt of 1977, H.R. Rep. No. 642, 95th Cong., 1st Sess. 15-18 (1977) (pt. II).

102. E.g., Letter from Chairman Harold M. Williams of the SEC to Chairman Peter W. Rodimo of the House Judiciary Committee (Sept. 8, 1977), reprinted in House Hearings, supra note 95, at 598. The SEC has also been a vigorous opponent of the proposed District of Columbia Bar rules.

103. H.R. 1, supra note 95.

104. 124 CONG. REc. H10,862 (daily ed. Sept. 27, 1978).

105. S. 555, 95th Cong., Ist Sess. (1977).

106. Pub. L. No. 95-521, 92 Stat. 1824 (1978) (codified in scattered sections of 2, 5, 18, 26, 28 U.S.C.A. (West Supp. 1979)) (amended 1979). The bill passed the Senate by voice vote on October 7, 1978, 124 CoNG. Rec. S17,497 (daily ed. Oct. 7, 1978), and the House by a vote of 370 to 23 on October 12, 1978, id. H12,59I (daily ed. Oct. 12, 1978). 
political benefit to be had in opposing this kind of legislation. Even if members did not believe it was particularly necessary or positive, they did not beheve it was sufficiently pernicious that a politically risky vote was called for."107

The coinpromises achieved in the conference committee highlight the inajor changes that the legislation made and what Congress saw as the most pressing policy concerns. ${ }^{108}$ First, both bills had purported to extend the prohibition of postgovernment activity to "aiding and assisting" clients as well as directly representing them before an agency. Both houses considered it inappropriate that an individual could do something mdirectly through an agent or partner that he or she could not do directly. The Senate bill would have prohibited "aiding and assisting" under section 207(a), and thus would have permanently banned such activity when it related to inatters in which the employee had "personally and substantially" participated.109 That prohibition would liave been consistent, of course, with the traditional rule of legal ethics. ${ }^{110}$ The House bill, on the other hand, would have categorized the "aiding and assisting" prohibition with the broader, but shorter (two-year) prohibition on activities within the former employee's "official responsibility." The compromise bill was narrower than either proposal. The prohibition on "aiding and assisting" applied to the twoyear, official responsibility cases, but only with respect to employees at level GS-17 or above and the comparable military ranks. ${ }^{111}$

Second, Congress dirccted most of its attention to new section 207(c), which prohibits any official contact between the former employee and his or her agency for a period of one year. Both louses saw this one-year ban as a very important "cooling-off period," but recognized that it would discourage many people from working for the agencies, including the young Securities and Exchange Commission attorneys discussed above. ${ }^{112}$ Because both houses viewed the prohibition as an attempt to limit former employees' ability to influence action simply through strength of personality and reputation, they were willing to restrict its coverage to high-ranking employees. The House bill would have applied to the more narrow category of persons with a rank of GS-16 and above whose positions are "excepted from the competi-

107. Personal interview with the author. In this Article, general observations made by persons interviewed are not attributed to the individuals by name.

108. S. Doc. No. 127 at 73-77.

109. See id. 74.

110. See notes 68-69 supra and accompanying text.

111. See S. Doc. No. 127 at 74 .

112. See text accompanying note 102 supra. 
tive service by reason of being of a confidential or policy making character." 113 The compromise bill kept the broader Senate coverage but limited the number of individuals affected by raising the grade level from GS-16 to GS-17. However, the Senate did accede to the House demand for a provision allowing the Director of the Office of Government Ethics to expand the coverage of this prohibition to include any other officer or employee "who has the role in the formulation of agency policy that is substantially similar to that exercised" 114 by the positions expressly covered.

Third, exceptions to the bill's coverage were a major issue. Congressman Eckhardt, for example, wanted to except all "hicensed professionals"-which presumably would have included lawyers-leaving them subject only to the ethical requirements of their state licensing authorities. The Senate bill proposed to exclude commumications that furnished scientific or technical infornuation to the government, and the House bill proposed to permit a former employee to make uncompensated appearances on behalf of himself. The Eckhardt amendment on "hicensed professionals" was rejected in conference, but the other two provisions were accepted. ${ }^{115}$

Fourth, the Senate bill created an "administrative remedy" for violations of section 207 that the House bill had not contamed. At first blush, it seems somewhat strange to provide a noncriminal remedy in a criminal statute. However, the Senate committee beheved that prosecutions were so few under the "knowing" requirement in the criminal statute that a more readily imposed remedy was desirable. ${ }^{116}$ The House accepted this provision. ${ }^{117}$

\section{F. The Events of 1979.}

Ordinarily, the passage of a major piece of legislation ends discussion, at least temporarily, on the subject on which it was passed. In the case of the revolving door phenomenon, however, legislation marked only the beginning of the debate. Most notably, several high-level officials in the Department of Health, Education, and Welfare threatened to resign before July 1, 1979, the effective date of the statute, in order to

113. S. Doc. No. 127 at 75.

114. Id.

115. The new provisions are codified in 18 U.S.C.A. $\S 207(f)$, (i) (West Supp. 1979).

116. Senate Comm. on Governmental Affairs, Report to Accompany S. 555, The Public Officials Integrity ACt of 1977, H.R. Rep. No. 170, 95th Cong., 1st Sess. (1977).

117. See S. Doc. No. 127 at 77.

The agencies were required to establish procedures for implementing this procedural remedy within six months of the effective date of the statute, i.e, by Jan. 1, 1980. 18 U.S.C.A. \& 207(j) (West Supp. 1979). 
avoid its provisions. Similar threats emanated from other agencies. ${ }^{118}$

Title IV of the new law ${ }^{119}$ created the Office of Government Ethics as a new part of the Office of Personnel Management and charged it with drafting regulations to implement the legislation. On February 16 , 1979, less than four months after passage of the statute, the chairmen and ranking minority members of both the House and Senate committees responsible for the law wrote a letter to the new Director of the Office of Government Ethics. ${ }^{120}$ In that letter, they referred to a "misunderstanding" regarding the meaning of amended section 207(b)(ii). In spite of that section's use of the term "official responsibility" to describe the scope of the barred activities, they asserted in the letter that "[b]oth the transcript and the report of the House-Senate conference demonstrate that this provision apphes only to those matters in which a former high-ranking official had been personally and substantially involved."121 They expressed their hope that the Director would find this construction of the statute "helpful" in issuing his regulations.

In addition, inore legislation was proposed to deal with the issues. Congressman Moorehead offered a bill to delete not only the "aiding and assisting" language, but also all the other changes directed at highranking employees. 122 Congressman Danielson proposed instead to delay the effective date of the legislation until January 1,1980 , im order to consider inore permanent revisions. ${ }^{123}$ On April 3, 1979, the Office of Government Ethics published a detailed set of regulations narrowly construing the "aidmg and assistmg" provision. ${ }^{124}$ According to these regulations, only "representational" assistance would be prohibited, not assistance in an "oral or written communication made with an intent to influence." 125 Similarly, the regulations permitted assistance in

118. E.g., Congress Ponders Delaying or Softening New Job Limits Amid Talk of Mass Exodus, 37 CoNG. Q. WeEkLY Rep. 512-13 (Mar. 24, 1979); Newsweek, supro note 11, at 51. The three HEW officials were former college administrators who feared that if they could not "aid and assist" members of their academic departments in handling government grants, they would have little to do.

119. Pub. L. No. 95-521, $\S \S 401-406,92$ Stat. 1824 (1978) (codified at 5 U.S.C.A. app. $\S \S 401$ 405 (West Supp. 1979)).

120. Letter from Hon. Abe Ribicoff, Charles N. Percy, George E. Danielson, and Carlos J. Moorehead to Bernhardt K. Wruble, Director, Office of Government Ethics (Feb. 16, 1979), reprinted in 125 CoNG. Rec. S1613 (daily ed. Feb. 21, 1979).

121. Id. While the legislators were undoubtedly sincere, there is no support in the statute and little support in the legislative record for their construction of the law. All that they could cite for their understanding was the unpublished transcript of the conference deliberations in which Senator Ribicoff had stated his understanding of the legislative intent. Id.

122. H.R. 2119 , 96th Cong., 1st Sess. (1979).

123. H.R. 2843, 96th Cong., 1st Sess. (1979).

124. Amendenents to 5 C.F.R. $\$ \$ 737.1$ to .29 (1979), 44 Fed. Reg. 19,974 (1979).

125. Id. 19,982 . Construed more broadly, the statutory language would seem to cover even a 
managing contracts and grants. ${ }^{126}$ Less than a week later, the Senate passed "clarifying" legislation proposed by the administration to confirm the new understanding of the "aiding and assisting" provision. ${ }^{127}$ Instead of assistance "concerning" an appearance before an agency, the amendment prohibited only assistance "by personal presence at" the appearance. It also made clear that the prohibitions extended to both "official responsibility" and "personal and substantial participation" cases. Finally, the ainendment excluded military officers in grades 0-7 and $0-8$, brigadier and major general, from automatic coverage.

Members of the House made an unsuccessful effort to delete all of subsection (c) of the origmal legislation that created the one-year ban on all advocacy contact with the former agency. ${ }^{128}$ A proposed sixmonth extension of the law's effective date was also defeated in committee. ${ }^{129}$ However, the House did pass an aunendinent lifting the oneyear ban for former officials working for colleges, universities, and similar nonprofit agencies and retaining the exclusion of one- and two-star generals from automatic coverage. ${ }^{130}$ After further consultation between committees, both the House and the Senate passed a compromise bill incorporating the major proposals of each bill only two weeks before the July 1 effective date of the original law. ${ }^{131}$

Even after these legislative "solutions," however, questions concerning the Act's application did not abate. In September 1979, the Second Circuit handed down its decision in Armstrong v. McAlpin. ${ }^{132}$ In March 1976, Michael Armstrong, receiver for Capital Growth Company, S.A. (Costa Rica), asked a New York firm to represent him in a suit against Clovis McAlpin, who allegedly had committed a securities

public speech by a former official that unintentionally helped (aided) a nonclient firm deal with the government.

126. Id. This issue had been of particular concern to the former academic admimistrators at the Department of Health, Education, and Welfare. See note 118 supra and accompanying text.

127. S. 869, 96th Cong., 1st Sess. (1979), 125 Cong. REC. S4241 (daily ed. Apr. 9, 1979).

128. H.R. REP. No. 115, 96th Cong., 1st Sess. 17, reprinted in [1979] U.S. CoDE CoNG. \& AD. NEws 1418, 1430.

129. Id.

130. H.R. Res. 281, 96th Cong., 1st Sess., 125 CoNG. Rec. H3696 (daily ed. May 24, 1979). This exclusion was a direct response to the concerns of Department of Health, Education, and Welfare officials. See note 118 supra and accompanying text. See Judiciary Panel Approves Weakened Job Restrictions, 37 CONG. Q. WEEKLY REP. 788 (Apr. 28, 1979).

131. Amendments to the Ethics in Govemment Act of 1978, Pub. L. No. 96-28, 93 Stat. 76 (1979) (to be codified at 18 U.S.C. $\$ 207(b)$, (d)(1)-(2)).

132. 606 F.2d 28 (2d Cir. 1979), hearing en banc granted, No. $79-7042$ (2d Cir. Dec. 12, 1979). Former government lawyers were disqualified in at least two other cases during 1979. Both cases involved former prosecutors who sought to become defense counsel in cases on which they had worked as prosecutors. United States v. Ostrer, 597 F.2d 337 (2d Cir. 1979), and United States v. Kitchin, 592 F.2d 900 (5th Cir. 1979) (per curiam), cert. denied, 100 S. Ct. 86 (1979). 
fraud that cost Capital Growth Company over $\$ 24$ million. The law firm had recently hired an associate named Theodore Altman, who had spent the previous eight years at the Securities and Exchange Commission and had been personally involved in a Commission proceeding against McAlpin concerning the same alleged fraud.

The firm recognized the possible ethical issues raised by Altman's presence, but concluded that the screening procedures called for in American Bar Association Formal Opinion No. $342^{133}$ would elimmate the problein. Moreover, the firm consulted the Securities and Exchange Commission and determined that the Commission had no objection to the firm's participation in the matter as long as Altman was not involved. McAlpin, however, moved to disqualify the firm because of Altman's work while at the Securities and Exchange Commission. The district judge denied the inotion. ${ }^{134}$

On review, the Second Circuit acknowledged American Bar Association Formal Opinion No. $342^{135}$ and Opinion No. 889 of the Association of the Bar of the City of New York, ${ }^{136}$ and recognized that the Board of Governors of the District of Colunibia Bar had endorsed screening as an adequate nieans of protecting the governinent and the public. It nonetheless reversed the district court. 137 While noting that "it would be entirely inappropriate to atteinpt to formulate a rule of general apphication respecting the law firm of a lawyer disqualified under DR 9-101(B) . . .,"138 the court found two inquiries relevant in each case. First, it questioned whether 'the 'matter' for which the disqualified lawyer had 'substantial responsibility' [was] the kind of matter where the risks against which DR 9-101(B) guards are present."139 Second, the court asked if "the 'substantial responsibility' that disqualifies the former government lawyer [resulted] from his active, personal participation in the matter or only from the nommal relationship of a supervisory official, such as an agency general counsel." 140

In the view of the Second Circuit panel,

[a] government attorney with direct, personal involveinent in a matter involving enforcement of laws that are the basis for private causes of action inust understand, and it must appear to the public, that there will be no possibility of financial reward if he succumbs to the

133. ABA OpInions, No. 342, supra note 74 . See notes 74-80 supra and accompanying text. 134. Armstrong v. McAlpin, 461 F. Supp. 622 (S.D.N.Y. 1978), rev'd, 606 F.2d 28 (2d Cir. 1979), rehearing en banc granted, No. 79-7042 (2d Cir. Dec. 12, 1979).

135. See notes 74-80 supra and accompanying text.

136. See note 80 supra.

137. $606 \mathrm{~F} .2 \mathrm{~d}$ at 28 .

138. Id. at 33.

139. Id.

140. Id. 
temptation to shape the government action in the hope of enhancing private employment. ${ }^{141}$

Screening, according to the court, cannot assure that an attorney is not compensated, either now or later, for attracting the business from which he is apparently screened. An "internal arrangement insulating fees from the disqualifying case . . . would most likely be unknown to casual observers and unpersuasive to the inore informed."142 The court acknowledged that there was no suggestion in this case that any improper considerations had actually motivated Altman; however, disqualification was "required as a prophylactic ineasure to guard against misuse of authority by government lawyers." 143 Since the Court of Claims had reached a result directly contrary to this decision only two years earlier, ${ }^{144}$ the law on this extremely sensitive question was left uncertain.

\section{Problems IN Establishing the Appropriate Limits on Private Activities After Government Service}

The preceding historical record suggests that the concern about the private activities of former government officials has existed for well over a century. The cries of alarm and hints of scandal, however, liave einerged durimg the last decade. After all the discussions and congressional debates, one would think that the subject had been clearly analyzed. However, several difficulties have precluded coinplete analysis: there seems to be no good information on the extent of the revolving door phenomenon, no clear breakdown of the questions comprising the revolving door issue, and no real consensus on the probleuns that the plienomenon creates.

\section{A. Difficulty Determining the Nature and Extent of the Revolving Door Phenomenon.}

One of the most difficult problems in assessing the significance of the revolving door phenomenon is the lack of empirical data. The General Accountimg Office tried to study the issue in 1978, but concluded that no reliable information was available, ${ }^{145}$ although it did report that "most agency officials contacted considered such problems at their agencies to be insignificant." 146 The report criticized the lack of

\footnotetext{
141. Id. at 34.

142. Id

143. Id. (footnote omitted).

144. Kesselhaut v. United States, 555 F.2d 791 (Ct. Cl. 1977).

145. GAO REPORT 6-7.

146. Id. 6.
} 
data, but recognized that the present law does not require-or even permit - an agency to ask departing employees what their next jobs will be. ${ }^{147}$ Several agencies have regulations requiring some disclosure by some officials, ${ }^{148}$ but the General Accounting Office found that even those regulations are largely unenforced. ${ }^{149}$

The best data available on this question pertains to the activities of former agency commissioners. In 1976, Common Cause studied nine agencies and assembled statistics on the number of commissioners who had coine originally froin industry and the number of commissioners who had left the government to take jobs in mdustry. ${ }^{150}$ According to the report, forty-eight percent of the resigning commissioners joined either a regulated company or a law firm serving regulated chents. ${ }^{151}$

Using similar data, the Senate Government Operations Comınittee found that results varied considerably from one agency to another. ${ }^{152}$ Eleven of the fifteen Securities and Exchange commissioners leaving office between 1961 and 1976 either conducted business or jomed a firm that conducted business subject to Securities and Exchange Cominission supervision. ${ }^{53}$ Eleven of the forty-eight Federal Communications and Federal Trade Commission commissioners studied had coine froin

147. Id. 11-13.

148. E.g., 16 C.F.R. $\S 4.1$ (b) (1979) (FTC); 17 C.F.R. $\S 200.735-2$ (1979) (SEC).

149. GAO REPORT 14-16.

150.

INTERCHANGE OF PERSONNEL

(For years 1971-1975)

\section{COMMISSIONERS}

\begin{tabular}{|c|c|c|c|c|}
\hline Agency & $\begin{array}{l}\text { Total number } \\
\text { appointed }\end{array}$ & $\begin{array}{l}\text { Number from } \\
\text { mdustry }\end{array}$ & $\begin{array}{l}\text { Total number } \\
\text { that } \\
\text { left agency }\end{array}$ & $\begin{array}{l}\text { Number who took } \\
\text { industry jobs }\end{array}$ \\
\hline
\end{tabular}

\begin{tabular}{|c|c|c|c|c|}
\hline FTC & 6 & 5 & 5 & 5 \\
\hline FPC & 5 & 2 & 6 & 0 \\
\hline ICC & 7 & 3 & 7 & $0^{*}$ \\
\hline SEC & 7 & 5 & 7 & 5 \\
\hline FCC & 7 & 5 & 7 & 4 \\
\hline CPSC & 5 & 2 & 0 & 0 \\
\hline FDA & 1 & 0 & 1 & 1 \\
\hline EPA & 2 & 0 & 1 & 1 \\
\hline NHTSA & 2 & 0 & 1 & 1 \\
\hline TOTALS & 42 & 22 & 35 & 17 \\
\hline
\end{tabular}

*ICC reported not knowing where two of the seven presently worked.

Common Cause Study 41.

151. Id. 40.

152. S. Doc. No. 25 at 65-68.

153. Id. 67. 
regulated industries, and twenty-four of the forty-eight were subsequently employed by these industries. ${ }^{154}$ At the Federal Maritime Commission, on the other hand, "few . . . inembers came from the regulated mdustry and few go there afterward."Iss Further, the committee found, whatever the formal affiliations of any of the former commissioners, "personal appearances by former regulators before the same agency [were] rather unusual." 156 The Senate committee also scrutinized the circumstances behind the statistics. For example, it cited a New York Times article on the law practice of William Ruckleshaus, former head of the Environmental Protection Agency, as one example of the problem in evaluating the revolving door phenomenon. ${ }^{157}$ According to the Times, nine lawyers in Ruckleshaus' law firm made at least 178 contacts over eighteen months with the Environmental Protection Agency. ${ }^{158}$ Analyzing this data, the committee concluded:

The firm's clients did mclude powerful trade associations . . . but the hon's share of the contacts appear routime: requests for public lists or reports; information on hearing dates; application for government funding for research and development. ... It was ample evidence of an active law practice, but what else did it establish? 159

The Senate committee also refuted press accounts suggesting improprieties in Manuel Cohen and Miles Kirkpatrick's postagency private practices. Cohen was a career Securities and Exchange Commission official who left when a change of administration forced him to relinquish the Commission chairmanship. Kirkpatrick was a prominent private lawyer who was coaxed into the Federal Trade Commission chairmanship after distinguished service at the head of an American Bar Association committee on the problems of that agency. The Senate committee concluded that the "Cohen and Kirkpatrick illustrations are by no means isolated examples. The private practice of law even in a regulatory specialty is not, ipso facto, an unconscionable culmination to years of public service." 160

None of this data, however, related to the probably more important issue of what is happening below the top-level, highly visible agency positions. In trying to answer that question, Common Cause and the Senate committee met with problems similar to those within

154. Id. $66 \mathrm{n} .113$. The committee was relying on J. Graham \& V. KRAmer, AppolntmenTs TO THE REGULATORY AGENCIES: FCC AND FTC (1949-1974) (1976).

155. S. Doc. No. 25 at 66.

156. Id.

157. N.Y. Times, Aug. 23, 1976, at 40, col. 1, cited in S. Doc. No. 25 at 65.

158. N.Y. Times, Aug. 23,1976 , at 40 , col. 1 .

159. S. Doc. No. 25 at 65.

160. Id. 64 . 
the General Accounting Office's experience. ${ }^{161}$ The Food and Drug Administration told the Senate committee, for example, that of the ninety-nine officials at levels GS-15 or above "who left the agency between 1971 and 1975, only nine either took jobs with regulated firms or served as consultants to those interests."162 However, Common Cause discovered that such data did not include any Food and Drug Administration lawyers, inany of whom had gone to work for law firms with regulated clients. ${ }^{163}$

The inherent lack of data has remained a problem in the preparation of this Article. Only two new, tangential pieces of information can be added. First, in an analysis done for this Article, ${ }^{164}$ the Securities and Exchange Commission determined that between January 1, 1974, and Deceinber 31, 1978, 604 einployees left the agency who were or will be required to file "Section 6(b) reports" 165 if they appear in a proceeding before the agency within two years from the date of their departures. The number of persons filing such reports thus far has been 182 , about thirty percent of the total. ${ }^{166}$ Assuming everyone has complied with the law, approximately seventy percent of the Securities and Exchange Commission employees have not appeared before the agency within two years since their departures.

Second, in 1976 the Federal Trade Commission einployed a manageinent consulting firm to study turnover at the agency. 167 That study indicated that the agency loses, on average, about one-sixth of its attorneys each year, a proportion almost equal to the attrition rate at the Antitrust Division of the Departinent of Justice and the Securities and Exchange Commission, but inuch higher than that of most private law firms. A further breakdown of the figures indicates that, of the 120 attorneys who left the Federal Trade Commission during the eighteenmonth study period, thirty-one percent had been employed there less than two years, another thirty-one percent were in their third year, and

161. See text accompanying note 145 supra.

162. S. Doc. No. 25 at 66 n.114.

163. Common Cause Study 48, 60-62. Technically, FDA lawyers are paid by the Department of Health, Education, and Welfare.

164. The study was done by Mr. William E. Ford, Assistant Director, Office of Personnel, Securities and Exchange Commission. His help is gratefully acknowledged.

165. Letter from William E. Ford to Thomas D. Morgan (Feb. 26, 1979). This filing requirement, set forth in 17 C.F.R. $\$ 200.735-8$ (b) (1979), states that a former SEC commissioner or employee must, for two years after leaving the SEC, file a statement with the Secretary of the Commission explaining the nature of any appearance he or she contemplates making before the Commission. The requirement is numbered " $6(\mathrm{~b})$ " in the Commission's Code of Conduct Rcgulations.

166. Letter from William E. Ford to Thomas D. Morgan (Jan. 29, 1979).

167. Meredith Associates, Inc., Study of Turnover at the FTC (on file at the FTC). 
thirty percent were in their fourth year. Thus, approximately twothirds of the departing attorneys had less than three years experience, and ninety percent had less than four years experience at the Federal Trade Commission. Two-thirds of these departing attorneys were found to have gone into private practice, and, perhaps significantly, forty percent of thein reportedly were recruited by counsel for respondents in Federal Trade Commission proceedings. ${ }^{168}$

Of course, even if sufficient information were available, there would still be disagreement about its correct interpretation. A inajor problem might exist if a large number of former employees were to appear before their respective agencies, and the problein would be expensive to eliminate. However, without such data there is no way to analyze the costs and benefits of present or proposed rules in other than general terms.

The preparation of this Article has necessarily required rehance on interviews and the published writings of present and former governinent officials, as well as of critics and defenders of the "revolving door" phenomenon. Ultimately, however, one inust candidly recognize that anyone's conclusions on this issue are unlikely to be based on concrete data.

\section{B. Issues To Be Addressed in Formulating Restrictions on Post- Employment Activity.}

To organize the revolving door phenoinenon for analysis, one inust break it down into several specific issues. There are at least fifteen issues that can be grouped under three general headings: the role of the eniployee while in government, the private role of the foriner einployee, and the inore general issues of enforceinent and policy.

1. The Role of the Employee While in Government. Should the law distinguish between the several types of jobs in which a governinental official might be employed? For exainple, sliould lawyers be treated differently froin persons administering federal contracts? Should either or both be distinguished froin technical personnel such as scientists or test pilots? The Ethics in Government Act nnakes special

168. Id. 9-17. The Common Cause study also contains several other attempts to estimate the extent of the revolving door phenomenon. Of 28 former government employees reported in the press to have gone to work for regulated companies or their law firms, at least 20 had personally contacted officials in their former agencies. CoMmon CAUSE STUDY 53-54. Of 1406 former military officers who took jobs with defense contractors, at least 379 became employed by firms within their former official jurisdiction. Id. 58. Further, of 1712 "semior employees" in government studied, 349 had come from private industry or law firms. Id. 41. 
provision for scientific and technical personnel, ${ }_{169}$ while the regulations promulgated by the Office of Government Ethics treat contracting personnel differently from lawyers im some situations. ${ }^{170}$ Are these distinctions arbitrary, or do they make sense?

Should the law distinguish between activities in which a former official was personally involved and those that fell only within his or lier official responsibility? As discussed earlier, the federal statute draws this distimction and provides different rules for each case. The American Bar Association Code of Professional Responsibility, for exainple, does not.

Sliould the former einployee's salary level or the nature of his or her job be a decisive factor, as distinguished froin his or her relationship to the particular decision or issue in question? Even after the 1979 modifications, the federal statute draws important distinctions based on the former characteristics, while, again, the American Bar Association Code and even the proposed District of Columbia Bar rules do not.

2. The Lawyer's Role in Private Life. Should the law distinguish between a former official's personal imtervention before a governmental agency and his giving private advice to another about how to approach the government? The present federal statute prohibits only the forner;

169. Section 207(f) provides:

The prohibitions of subsection (a), (b), and (c) shall not apply with respect to the making of communications solely for the purpose of furnishing scientific or technological information under procedures acceptable to the department or agency concerned, or if the head of the department or agency concerned with the particular matter, in consultation with the Director of the Office of Government Ethics, makes a certification, pubhished in the Federal Register, that the former officer or employee has outstanding qualifications in a scientific, technological, or other technical disciphine, and is acting with respect to a particular matter which requires such qualifications, and that the national interest would be served by the participation of the former officer or employee.

18 U.S.C.A. $§ 207$ (f) (West Supp. 1979).

170. Compare, for example, the way the regulations treat the issue of what constitutes the same "particular matter" in 5 C.F.R. \& 737.5(c)(4) (1979):

Example 1: A government enployee was substantially involved in the award of a long-term contract to $Z$ Company for the development of alternative energy sources. Six years after he terminates Government employnent, the contract is still in effect, but mucl of the technology has changed as have inany of the personnel. The Government proposes to award a "follow on" contract, involving the same objective, after conpetitive bidding. The employee may represent $Q$ Conpany in its proposals for the follow-on contract, simce $Q$ Company's proposed contract is a different inatter from the contract with $Z$ Company. He may also represent $Z$ Conpany in its efforts to contimue as contractor, if the agency determines on the basis of facts referred to above, that the new contract is significantly different in its particulars fron the old: The former employee should first consult his agency.

Example 2: A Government employee reviewed and approved certam wiretap applications. The prosecution of a person overheard during the wiretap, although not originally targeted, must be regarded as part of the same particular inatter as the initial wiretap apphication. The validity of the wiretap may be put in issue and many of the facts giving rise to the wiretap application would be involved. 
the 1978 amendments, on the other hand, followed the suggestion of Common Cause and prohibited both. ${ }^{171}$

Should it matter whether the former employee's private role before the agency consists of advocacy, imquiry, or some other role? In other words, should it matter whether the employee is seeking to get something more than information from the government? The federal statute seems to be construed to forbid only advocacy, ${ }^{172}$ but inquiry is often at least as valuable an activity for private clients.

Should it matter whether the former employee's private role is related to a specific case he handled, cases similar to those he handled, or a more general rulemaking proceeding in which he was involved? Again, the federal statute prohibits only the first situation, but the District of Columbia Bar proposal would regulate the last situation as well. 173

Should the bar to the former employee's activity extend only to his or her own former agency or should it extend to the entire government? Should a former Air Force contracting officer, for example, be barred from subsequent dealings with the Air Force, the Department of Defense, all "aerospace" agencies (such as the National Aeronautics and Space Administration), or the entire federal government? The nine-

171. This was the significance of adding the words "by personal presence at" to the "aiding and assisting" language of section 207(b)(ii). Common Cause had not been the only proponent of the broader approach; the 1962 report by the Association of the Bar of the City of New York had also called for it. BAR REPORT 292.

172. Subsections (a), (b), and (c) of section 207 prohibit "any formal or informal appearance before" as well as any "intent to influence . . . any oral or written communication." 18 U.S.C.A. $\S$ 207(a)-(c) (West Supp. 1979), as amended by Pub. L. No. 96-28, 93 Stat. 76 (1979). 5 C.F.R. $\S 737.5(a)(3)(1979)$ treats these concepts together:

(3) Appearances; communications made with intent to infuence. An appearance occurs when an individual is physically present before the United States in either a formal or informal setting or conveys material to the United States in connection with a formal proceeding or application. A communication is broader than an appearance and includes correspondence, a telephone call, or other ineans.

How one is ever "physically present before the United States" is left unexplained, but under these definitions it at least seems clear that the statute does not reacls telephone inquiries.

173. The Board of Governors went beyond the proposal of its Ethics Committee, wlich had favored a one-year ban. DR 9-101(E) of the present proposal provides:

For five years after leaving public office or einployenent, a lawyer shall not personally participate in counseling or otherwise representing any chent

(1) with respect to the adoption of any provision of a proposed mle or regulation of general applicabihity, if the lawyer previously participated personally and substantially as a public officer or employee in the drafting of or the decision to propose such proposed provision, or

(2) in challenging the validity of any provision of a rule or regulation of general applicability, if the lawyer previously participated personally and substantially as a pubhic officer or einployee in the drafting of or the decision to propose or to adopt such provision.

Final Revolving Door Proposal, supra note 9, at 51. 
teenth century statutes had the broadest possible sweep, ${ }^{174}$ and, in theory, the present statute does as well. Because the bar is limited to specific matters, however, the practical effect is that the former employee will not be barred beyond his or her own agency.

What restrictions should be placed on dealings with potential future employers while the employee is still in government service? Traditionally, this question has not been deemed a postemployment issue, ${ }^{175}$ but there may be a subtle interplay between an employee's decisions while in government service and his hope for a job at the end of that service. If no absolute bar is placed on accepting a job in the industry affected by one's former government agency, for example, should negotiations for that subsequent job be prohibited prior to resigning froin federal service?

Should all activity that is related to the former einployee's governinent service be prohibited or only activity that is contrary to the government's interest? For example, should a former einployee be permitted to take advantage of information that a private party submitted to the government in confidence? Again, the federal statute appears to limit only actions contrary to the government's imterest, ${ }^{176}$ although the American Bar Association Code of Professional Responsibility prohibits both. ${ }^{177}$

\section{General Procedural and Enforcement Issues. How long should}

174. See text accompanying notes 17-23 supra.

175. Indeed, the question did not come up in the 1978 and 1979 congressional deliberations. The changes proposed were to section 207 , while the pressures on present government officials are governed by section 208 .

176. The statutory language in subsections (a)(2) and (b)(2) refers to "particular inatter[s] . . in which the United States . . is a party or has a direct and substantial interest . . ." 18 U.S.C.A. \$ 207(a)(2), (b)(2) (West Supp. 1979), as amended by Pub. L. No. 96-28, 93 Stat. 76 (1979). That language has been construed in 5 C.F.R. \& 737.5(c)(5) (1979) not to reach most subsequent private actions, but "[t]he importance of the Federal interest in a inatter can play a role in determining whether two matters are the saine particular inatter." Id.

Example 1: An attorney participated in preparing the Government's antitrust action against $Z$ Company. After leaving the Government, she may not represent $Z$ Company in a private antitrust action brought against it by $X$ Company on the same facts imvolved in the Government action. The interest of the United States preventing inconsistent results and the appearance of impropriety in the sane factual matter involving the saine party, $\mathbf{Z}$ Company, is direct and substantial. However, if the Government's antitrust investigation or case is closed, the United States no longer has a direct and substantial interest in the case.

Example 2: A inember of a Government teain providing technical assistance to a foreign country leaves and seeks to represent a private contractor in securing a contract to perform the same service. The proposed new contract may or inay not be considered a separate inatter, depending upon whether the Umited States has a national interest in inaintaining the original contract. The agency involved inust be consulted by the forner Id. employee before the representation can be undertaken.

177. ABA CODE DR 9-101(B). See note 68 supra. 
the bar to postemployment activity extend? Should the answer vary for different kinds of activity? What is the justification, if any, for making the ban permanent? The federal statute establishes a permanent ban for matters in which the employee was "personally and substantially" involved, and a two-year ban for matters within his "official responsibility." 178

Sliould the disqualification of a former government employee extend to his partners, associates, or the organization for which lie works? If attribution is possible, should it or the employee's own disqualification be subject to waiver by the government? What kind of procedure for waiver sliould be adopted? Who should be empowered to grant a waiver-the agency involved, the Office of Government Ethics, an independent federal judge? May conditions be placed on the waiver? These considerations constitute a inajor portion of the difference between the positions of the American Bar Association and the District of Columbia Bar. ${ }^{179}$ The federal statute has tended to skirt the issues, ${ }^{180}$

178. 18 U.S.C.A. $§ 207$ (West Supp. 1979), as amended by Pub. L. No. 96-28, 93 Stat. 76 (1979).

179. See text accompanying notes $89-94$ supra. The text of the present District of Columbia Bar proposal is as follows:

DR 9-102 Imputed Disqualification of Partners, Associates, and Of Counsel Lawyers.

(A) If a lawyer is required to decline or to withdraw from employment under DR 9101(B), on account of personal and substantial participation in a matter other than as a law clerk, no partner or associate of that lawyer, or lawyer with an of counsel relationship to that lawyer, may accept or continue such employment except as provided in (B) below.

(B) The prohibition stated in DR 9-102(A) shall not apply if the personally disquahified lawyer is screened from any form of participation in the matter or representation as the case may be, and from sharing in any fees resulting therefrom. In order to ensure such screening,

(1) the personally disqualified lawyer shall file with the public department or agency and serve on each other party to any pertimeut proceeding an affidavit attestimg that during the period of his or her disqualification the personally disqualified lawyer will not participate in any manner in the matter or the representation, will not discuss the inatter or the representation with any partner, associate, or of counsel lawyer, and will not share in any fees for the matter or the representation; and that the personally disqualified lawyer will file and serve, promptly upon final disposition of the matter or upon expiration of the period of personal disqualification, whiclever occurs sooner, a further affidavit describing his or lier actual compliance with these undertakings.

(2) At least one affiliated lawyer sliall file with the same department or agency and serve on the same parties an affidavit attesting that all affiliated lawyers are aware of the requirement that the personally disqualified lawyer be screened from participating in or discussing the matter or the representation and describing the procedures being taken to screen the personally disqualified lawyer; and that at least one affiliated lawyer will file and serve, promptly upon final disposition of the matter or upon expiration of the period of personal disqualification, whichever occurs sooner, a further affidavit describing the actual compliance by the affiliated lawyers with the procedures for screening the personally disqualified lawyer.

(C) If a personally disqualified lawyer or an affiliated lawyer has stated in accordance with DR 9-102(B) that further affidavits describing compliance with screening procedures will be filed and served upon final disposition of the matter or upon expiration of 


\section{and the cases are spht. 181}

What should be the sanctions for violating any of the restrictions on posteinployment activity? Should there be criminal penalties? Should the government be able to prevent an offending official froin participating in the particular inatter in question? Should the penalty extend to future dealings with the former agency? ${ }^{182}$ What procedures should be devised for enforcing any sanctions? ${ }^{183}$

Should the rules adopted deal only with the departure of einployees from government, or with their entrance to government as well? Are the concerns sufficiently similar that they should be treated together? Only the proposed District of Columbia Bar rules deal with government entry; ${ }^{184}$ under other rules the door only revolves out.

Who can establish rules relating to the activities of former govern-

the period of disqualification, such affidavits shall be filed and served as soon as practicable after they are due.

(D) Affidavits filed pursuant to DR 9-102(B) and (C) shall be public except to the extent that a lawyer submitting an affidavit shows that disclosure is inconsistent with Canon 4 or provisions of law.

Final Revolving Door Proposal, supra note 9, at 55-56.

180. The 1962 version of section 207 seemed to provide expressly that a former einployee's disqualification would not be imputed to his or her partners and associates. See note 57 supra. That express disclaimer was deleted in the 1978 amendments. It can thus be argued that inputation is now an open issue. However, nothing in the legislative history suggests that this deletion of the last sentence of former section 207 was more than editorial license or that it was intended to have substantive effect.

181. Compare Kesselhaut v. United States, 555 F.2d 791 (Ct. Cl. 1977) (a decision disqualifying the former employee but not attributing disqualification to the law firn) with Armstrong v. McAlpin, 606 F.2d 28 (2d Cir. 1979), rehearing en banc granted, No. $79-7042$ (2d Cir. Dec. 12, 1979), United States v. Kitchin, 592 F.2d 900 (5th Cir. 1979) (per curiam), cert. denied, 100 S. Ct. 86 (1979), Telos, Inc. v. Hawaiian Tel. Co., 397 F. Supp. 1314 (D. Hawaii 1975) (former deputy attorney general), and Handelman v. Weiss, 368 F. Supp. 258 (S.D.N.Y. 1973) (disqualified partner formed firm) (decisions disquahfying law firm because of the presence of a disqualified partner or associate).

182. 18 U.S.C.A. \& 207(j) (West Supp. 1979) provides in part:

If the head of the department or agency in which the former officer or einployee served finds, after notice and opportunity for a hearing, that such former officer or employee violated subsection (a), (b), or (c) of this section, such departinent or agency head may prohibit that person froin inaking, on behalf of any other person (except the United States), any informal or formal appearance before, or, with the intent to influence, any oral or written commumication to, such department or agency on a pending matter of business for a period not to exceed five years, or may take other appropriate disciphinary action. Such disciplinary aetion sliall be subject to review in an appropriate United States District Court.

183. Section 207(j) continues: "No later than six inonths after the effective date of this Act, departments and agencies shall, im consultation with the Director of the Office of Government Ethics, establish procedures to carry out this subsection." Id. Basic guidelines are set out in the regulations. 5 C.F.R. $\$ 737.27$ (1979).

184. Proposed DR 9-101(C) for the District of Columbia Bar provides: "A lawyer serving as a public officer or employee shall not participate in any inatter in which he or she participated personally and substantially while in private practice or nongovernmental einployment." Final Revolving Door Proposal, supra note 9, at 49. 
ment officials? Should Congress adopt a uniform policy? Should individual agencies be permitted to go beyond the requirements Congress has established? 185 Should bar associations or otler professional groups be permitted to establish enforceable ethical standards that are more restrictive than the rules imposed by the statute? ${ }^{186}$

Should a grandfather primciple be applied? That is, should the rules that are adopted apply to all former government einployees, regardless of when they were employed, or should the rules be enforced only with respect to persons leaving (or entering) government service hereafter? ${ }^{187}$

\section{The Costs and Benefits of Regulating the Activities of FORMER GOVERNMENT OFFICIALS}

As shown in the preceding section, little is known about the nature and extent of the private work of former government officials. Furtler, the breadtli and variety of specific questions that underlie the "revolving door" debate lead to the recognition that even more basic questions must be answered. What is it that former government einployees offer subsequent private employers? In wliat ways, if any, miglit the governinent and the public be damaged by a lack of restrictions on the private activities of sucli former employees? What are the costs, if any, to the government itself wlien it seeks to regulate tliese activities?

\section{A. What Former Government Officials Bring to Private Employers.}

Asking what former government einployees lave to offer private employers is a particularly useful way to approacli the question of what limitations slould be imposed. Questions about the experience or otlier attributes that inake former officials desirable employees can never be answered definitively, because every hiring decision is in some

185. Nothing in the statute appears to permit agencies to demand more, although in interviews with this author, staff members charged with drafting the legislatiou stated that there was no intent to limit the agencies. See S. REP. No. 170, 95th Cong., 2d Sess. 155 (1978), reprinted in [1978] U.S. Code Cong. \& AD. NEws 4216, 4371.

186. The Justice Department has specified that it does not believe that the District of Columbia Bar, or any other local bar, should establish its own principles beyond those estabhished by Congress. Letter from Associate Attorney General Michael J. Egan to William H. Allen, Chairman, Legal Ethics Committee of the District of Columbia Bar"(Feb. 15, 1978).

187. The District of Columbia Bar proposal recognized the issue but dealt with it as follows: Proposed Text of Order Adopting The Amendments

The amendments to Canon 9 inade by this order are effective as of the date hereof, except that they shall not be construed to require a lawyer or firm to terminate or withdraw from professional employment with respect to any particular matter as to which disqualification would otherwise apply if the employment with respect to such matter is in progress at the date hereof.

Final Revolving Door Proposal, supra note 9, at 60. 
way unique. Interviews with Washington lawyers, however, indicate that there are three characteristics of former government officials that stand out as inost important.

First, the former official will normally have acquired considerable expertise with the subject matter of his or her agency. For example, a former official of the Antitrust Division of the Department of Justice will tend to be relatively expert in antitrust law. Although it is possible to obtain coinparable expertise working for a private firın, subject matter expertise is nonetheless a primary reason why former government officials are considered attractive and einployable. This is especially true in the case of lower level government enployees.

Second, former government officials often have a better than usual sense of process. That is, they tend to understand how the government bureaucracy works and how decisions are made. They may know, for exainple, when it is appropriate and effective to intervene or challenge, and how to prepare the appropriate pleadings or documents. They also tend to be able to sense whether the agency will grant their new ennployer's desired rehef, or whether legislative change will be required.

Third, soine former government employees appear to be retained at least partly because they are celcbrities. Persons who have been in the public eye may attract clients by their very visibility. ${ }^{188}$

It is difficult to say whetler using a reputation attained through government service to gain private einployment is inherently improper. An accumulation of experience, understanding, and recognition is alinost inevitable for a successful government einployee, and is something no reasonable systein would seek to prevent.

\section{B. Problems the "Revolving Door" is Thought to Present.}

Looking beyond these seemingly innocuous reasons for hirmg foriner government employees, one is struck by the lack of consensus on what problems are raised by the revolving door phenoinenon. The saine Senate committee responsible for the extensive 1978 revisions of section 207, for example, had concluded after careful examination just a year earlier that the probleins were relatively slight, and that "we should be cautious in adopting new, nore strimgent restrictions."189

One factor that has confused analysis of the "revolving door" issue has been the tendency to treat it as a question of personal honesty and

188. The process is not necessarily as shallow as it may appear. In the case of lawyers, a company's regular counsel often selects Washington counsel. Thus, professional fame may be more controlling than celebrity status in the usual sense.

189. S. Doc. No. 25 at 67. 
morality. Certainly the government is entitled to scrupulously honest einployees, but most of the revolving door concerns do not involve actual honesty or dishonesty at all. Although morality is one dimension of "ethical" behavior, inany ethical issues, includimg the revolving door phenomenon, can best be understood as accommodating a number of values or concerns about the operation of given mstitutions - in this case, government agencies. ${ }^{190}$ A few of these concerns relate to honesty, others to public confidence, and others to perceptions of fairness. To the extent that appearances of impropriety are more or less widely perceived and are the subject of real concern, they too are appropriate for consideration. Arguments about morality in government, however, can often cloud rather than clarify these issues.

No single critic has set forth all the objections raised to service with an industry one has previously regulated, but six basic objections seem to recur. Perhaps because many of the critics are lawyers, several of the concerns have their roots in general principles of legal ethics. ${ }^{191}$

1. Protection of Client Confidences. The concern is sometimes expressed that a forner government employee will compromise confidential official inforination. ${ }^{192}$ If a prosecutor has been im the grand jury room interviewing witnesses under oath and in secret, for example, it obviously would be inappropriate for that prosecutor to resign his position and become defense counsel. ${ }^{193}$ Likewise, it might be thought improper if a government liealth official were hired by a drug company

190. This treatment of ethical issues as a question only of morality is a recurring problem in the discussion and analysis of legal ethics issues. See T. Morgan \& R. Rotunda, Problems and Materials on Professional Responsibility 1-5 (1976); Comment, The Lawyer's Moral Paradox, 1979 DuKE L.J. 1335, 1335-49.

191. The present ABA Code of Professional Responsibility deals expressly with the former government lawyer in DR 9-101(B) and EC 9-3. The Code, however, does not refer directly to the general question of when an individual may take a case that puts him in a position contrary to that of a former client. Sucl reprcsentation is not a traditional conflict of interest. The concern represented by the conflict prohibitions of the ABA Code is that the lawyer's independent professional judgment in a present case might be affccted by an existing conflict. See, e.g., ABA CODE DR 5105(A), (B) and EC 5-14 to 5-19. There is usually no reason to believe that the lawyer will be less loyal to his present clients because of his representation of a prior client. Indeed, the only reason why the "former client" problein seems to be called a "conflict of interest" is because the old $A B A$ Canons of Professional Ethics included this problein with traditional conflicts in its Canon 6 . See text accompanying notes 28 supra.

192. See, e.g., the FTC's proposed amendment to 15 C.F.R. \& 4.1(b)(3)(iii), whicls refers to "nonpublic documents or information pertaining to [a] matter . . . [that] came to the attention of the . . . employee or would be likely to have come to his attention in the course of his duties." 43 Fcd. Reg. 35,949 (1978). See also the SEC's rule set forth in 17 C.F.R. $\$ 200.735-8$ (1979), which bars participation in a matter by anyone who "gamed knowledge of the facts" of a case while at the Commission.

193. E.g., United States v. Ostrer, 597 F.2d 337 (2d Cir. 1979); United Statcs v. Nasser, 476 F.2d 1111 (7th Cir. 1973); Telos, Inc. v. Hawaiian Tel. Co., 397 F. Supp. 1314 (D. Hawaii 1975). 
and revealed to the company current thinking about changes in testing standards. The obligation of any attorney not to "use the confidences or secrets of a client for the advantage of a third person" 194 is continuous; ${ }^{195}$ termination of the lawyer-client relationship does not end the obligation. Anytime a lawyer takes a case against a former client, there is at least the possibility that confidential information supplied to the attorney in the prior case will be used contrary to the former client's interests.

The concern that former government employees may coinpromise confidential government information, however, is not a valid concern in many situations. Certainly in most contract and research relationships, exchange of information is to be desired, not restricted. Even in nore adversary situations, the Freedom of Information ${ }^{196}$ and Government in the Sunshine Acts ${ }^{197}$ have sigmificantly reduced the secrecy in government functions. Further, even if something is confidential one day, it will rarely be so forever, or even for one or two years. Of course, there is certainly still soine residue of valid government secrecy, ${ }^{198}$ and confidentiality might be one justification for some limits on the actions of former government einployees. ${ }^{199}$ However, one should be wary about too glib an assertion that protection of client confidences necessitates imposing sigmificant restrictions on future employment.

2. Switching Sides. It is often argued that there is something inherently and fundamentally wrong when a former governmental official "switches sides" and moves into the private sector.200 This argument is another adaptation of a longstanding rule of legal ethics-

194. ABA CODE DR 4-101(B)(3).

195. Id. EC 4-6.

196. 5 U.S.C. $\$ 552$ (1976).

197. 5 U.S.C. $\$ 522 b$ (1976).

198. See, e.g., R. Berg \& S. KLITZMAN, AN INTERPRetive Guide to THE Government iN THE SUNSHINE ACT (1978); Litigation UNDER THE AMENDED FREEDOM OF INFORMATION ACT (4th ed. C. Marwick ed. 1979).

199. Perhaps the most serious potential abuse of confidence is one over which section 207 expresses little concern. It is the possibility that a government employee might, im a subsequent private case, exploit inside information that the government obtamed by compulsion. The concern is not the compromise of the government's own secret; rather, the fear is that a former government lawyer might use information agamst a private defendant who was compelled to disclose that information under circumstances in which the information would not be normally available to other than a government employee. For example, an Internal Revenue Service agent may acquire information from a tax return that is useful in a subsequent private suit agamst the taxpayer. Cf. Armstrong v. McAlpin, 461 F. Supp. 622 (S.D.N.Y. 1978), rev'd, 606 F.2d 28 (2d Cir. 1979), rehearing en banc granted, No. $79-7042$ (2d Cir. Dec. 12, 1979) (former SEC employee had investigated firm now being sued on behalf of private chent).

200. See, e.g., S. Doc. No. 25 at 68 ("a deep, public uneasiness with officials who switch sides"); Committee on Legal Ethics, D.C. Bar, Tentative Draft Opinion for Comment in Response to 
the rule that prohibits a lawyer froin switching sides in a particular case. ${ }^{201}$ A defense lawyer, for example, may not move over to the prosecution table in the middle of the trial. In this situation, the reason for the rule seems obvious: communication of confidential information between attorney and client has likely occurred. The client may believe that this information has been used agaimst him, even if, in fact, the attorney had someliow ignored or not disclosed that information.

Obviously, the argument has little application to former officials other than lawyers. It is not disloyal for a cancer researcher to return to an academic or an industrial laboratory after working at a government laboratory. A retired military officer is not a traitor for continumg his work on a development program after being hired by a contractor. In such situations one could argue that no "sides" are involved or that the government and the private employers are on the same "side." Disqualification should be limited to situations in which there is truly a danger that confidential information will be abused. The general concern about "switching sides" is inuch too broad to use as a basis for analyzing the propriety of former officials' activities.

Further, even for lawyers, the argument is narrower than it first appears. While the lawyer traditionally may not appear on the other side of the same case, he is not barred from taking another case against the former client unless the cases are "substantially related" 202 or the representation would abuse the confidence or secrets of the former cli-

Inquiry 19, DisTRICT LAW., Fall 1976, at 41 ("a point which the sophisticated attorney and the unsophisticated .. . public are most likely to view in different ways").

201. The case Hull v. Celanese Corp., 513 F.2d 568 (2d Cir. 1975), illustrates the switching sides problem. Joan Hull had filed suit against Celanese alleging sex-based employment discrimination. Donata Deluhio, an attorney on the corporate legal staff of Celanese was actively involved in the defense of the suit, and attended interviews with company personnel and conferences with outside consultants who were lelping to prepare the statistical defense. About six months after beginning work on the case, Delulio decided that she lad gronnds for a discrimination complaint similar to Hull's. Delulio discussed the facts of her own case with the firm representing Hull. Celanese countered by seeking to disqualify Hull's firm. The motion was allowed by the district court, and affirmed by the court of appeals. Even though Delulio had not becoine counsel for Hull, the court found that Hull's counsel had access to her insights about Celanese and its defense. The effect on Celanese was found by the court to be "no less damaging" than if Delulio liad actually appeared for the plaintiffs. See also United States v. Trafficante, 328 F.2d 117 (5th Cir. 1964); Hilo Metals Co. v. Leamer Co., 258 F. Supp. 23 (D. Hawaii 1966).

202. The case that first establislied this rule was T.C. \& Theater Corp. v. Warner Bros. Pictures, Inc., 113 F. Supp. 265 (S.D.N.Y. 1953). Thomas Cooke lrad been the attorney for Universal Pictures Co. im an antitrust action filed by the government against Universal and several other film producers, challenging the practice of releasing films to a few houses for first-run slrowing before releasing them to the remaining distributors. Later, Cooke sought to represent a private plaintiff in a treble damage action against Universal for local consequences of the same practices. Cooke asserted that his only role on Universal's behalf had been entering the final order and handling the appeal in the Supreme Court. Thus, he asserted, he liad worked only witl a "cold record" and had been entrusted with no chent confidences. Further, lie argued, the government action and the 


\section{ent. ${ }^{203}$ It is not disloyalty to the government chent that should be the}

subsequent private action were not the "same case," so that the rule of automatic disquahification should not apply.

Judge Weinfeld rejected Cooke's contentions:

I hold that the former client need show no more than that the matters embraced within the pending suit ... are substantially related to the matters or cause of action wherein the attorney previously represented ... the former client. The Court will assume that during the course of the former representation confidences were disclosed to the attorney bearimg on the subject matter of representation. It will not inquire into their nature and extent. Only in this inanner can the lawyer's duty of absolute fidelity be enforced and the Spirit of the rule relating to privileged communications be maintained. . . . Lawyers should not put themselves in the position "where, even unconsciously, they inight take, in the interest of a new client, an advantage derived or traceable to, confidences reposed under the cloak of a prior, privileged relationship." In cases of this sort the Court must ask whether it can reasonably be said that in the course of the former representation the attorney might have acquired information related to the subject of his subsequent representation. If so, then the relationship between the two inatters is sufficiently close to bring the later representation within the prohibition of Canon 6 . In the instant case I think this can be said.

113 F. Supp. at 268-69. See also Government of India v. Cook Indus., Inc., 569 F.2d 737 (2d Cir. 1978); American Can Co. v. Citrus Feed Co., 436 F.2d 1125, 1128 (5th Cir. 1971); Motor Mart, Inc. v. Saab Motors, Inc., 359 F. Supp. 156 (S.D.N.Y. 1973).

At least two cases illustrate that courts may expand the "substantial relation" rule far beyond its reasonable scope. For example, in Chugach Elec. Ass'n v. United States Dist. Court, 370 F.2d 441 (9th Cir. 1966), the disqualified attorney had been general counsel for the defendant corporation. After some years in that position, the attorney resigned. Later, he brought suit on behalf of a new chent charging his former employer with attempting to destroy the client. All alleged acts occurred after the attorney had left the corporation.

The court's rationale for disqualifying the attorney was that "knowledge of private inatters gained in confidence would provide him with greater insight and understanding of the significance of subsequent events in an antitrust context and offer a promising source of discovery." $\mathrm{Id}$. at 443. Further, the court held that "he was in a position to acquire knowledge casting light on the purpose of later acts and agreements." $I d$.

The attorney in Chugach Electric had no inside infornation as to the events underlying the specific suit. Further, while working for the defendant, he had no way to subvert its position and make his present suit any more likely to succeed. In short, this appears to be a case in which the attorney was improperly disqualified and forbidden to use his background and experience to benefit a plaintiff who allegedly had been wronged.

An even more celebrated example of inproper disqualification is Eunle Indus., Inc. v. Patentex, Inc., 478 F.2d 562 (2d Cir. 1973). David Rabin, a textile patent attorney, represented hicensees of patents held by Burlington Industries and its subsidiary, Patentex, in a challenge to another firm's patent for Supp-hose stockings. Burlington and Patentex were interested in the resnlt of this litigation, because a successful result would allow their licensees to use their patent without fear of infringement of the Supp-hose patent. When Burlington and Patentex intervened in the suit, a counterclaim was filed by the owner of the Supp-hose patent alleging that Burlington and Patentex were attempting to inonopolize the field and destroy the defendant's competing patent. Rabin won this first case on behalf of the licensees and Burlington-Patentex.

In the second case, Rabin filed a suit against Burlington-Patentex on behalf of essentially the same licensees when Patentex sought to impose a tougher liceusing agreement. Patentex's response was a motion to disqualify Rabin. The district court granted the inotion, and the court of appeals affirmed. The court held that the situation required

[a] strict prophylactic rule to prevent any possibility, however shight, that confidential information acquired from a client or a previous relationship may subsequently be used to the chent's disadvantage.

Moreover, the court need not, indeed cannot, inquire whether the lawyer did, in fact, receive confidential information during his previous employment which might be 
subject of concern.

The switching sides argument appears to reflect a suspicion that lawyers should not defend one side of an issue one day and the other side the next. To do so "appears improper" to some observers, especially if the movement is between government regulator and private practice. Although "appearance of impropriety" is an ambiguous phrase, it apparently refers to the situation in which the lawyer is in a position to be disloyal if he so chooses. Even if an individual lawyer is of the highest moral character, the appearance of impropriety concept seeks to prevent his creating situations in which he cannot demonstrate that he was not dishonest.

Ultimately, this argument is unanswerable because the lack of integrity and fairness, if any, is largely in the eye of the beholder. Almost anything night look suspicious to someone. The Fifth Circuit, however, has put the appearance of impropriety in perspective: "It does not follow ... that an attorney's conduct nust be governed by standards which can be imputed only to the most cynical nembers of the pubhic. . . . [T]here niust be at least a reasonable possibility that some specifically identifiable impropriety did in fact occur." 204

used to the client's disadvantage. Suclı an inquiry would prove destructive of the weiglity policy considerations that serve as the pillars of Canon 4 of the Code....

\section{Id. at 571 .}

Because the issue of Burlington's relation to Patentex laad been raised in a counterclaim in the earlier case, it was held that Rabin could not raise a similar issue on behalf of the plaintiffs in this case. The court's own recitation of the facts of the case makes it appear that, if anything, Rabin was manipulated by Burlington into the situation that the company then relied upon to disqualify him. The "appearance of impropriety" relied on by the court is an important concept, but it is a phrase that can sometimes be used unthinkingly to justify results less equitable than the results tliey seek to prevent.

203. Scliloetter v. Railoc of Ind., Inc., 546 F.2d 706 (7th Cir. 1976), illustrates the potential sweep of this rule. In this suit for patent infringement, the record showed that the plaintiffs original patent application had been processed and defended froin cliallenges by a Mr. Jeffery. Purely by comcidence, the defendant in the later infringement action was represented by the firn Mr. Jeffery had been with at the time he had represented the plaimtiff. Although Mr. Jeffery was no longer a nember of that firm, the plaintiff sought to disqualify the defendant's counsel. The court of appeals leeld that if Mr. Jeffery were attempting to represent the defendant, his disqualification would be required. The confidential infornation that he was presuined to liave would be imputed to the other inembers of the firn and cause their disqualification. The court held that the district court liad not abused its discretion in finding that Jeffery's former finn had failed to overcome the presumption that Jeffery had passed confidential information on to his partners. Further, even though Jeffery had left the firm, he was a nnember of an "associated firn" in Washington, and thus, for this reason as well, the relationship was close enough to justify disqualification. Id. at 711, 712. See also NCK Organization, Ltd. v. Bregman, 542 F.2d 128 (2d Cir. 1976); cf. Wilson P. Abraham Const. Corp. v. Armco Steel Co., 559 F.2d 250 (5th Cir. 1977) (counsel liad represented codefendant and had access to inultidefendant conferences).

204. Woods v. Covington County Bank, 537 F.2d 804, 813 (5th Cir. 1976). The Senate Government Operations Committee proposed to add to the test the language "or . . . might occur." S. Doc. No. 25 at 43. 
Switching sides, in general, does not raise problems of either honesty or specific impropriety. While the interest in preserving client confidences and confidence is critical, the interest of a lawyer in the ability to file a suit to redress real wrongs, and the interest of a client in not having his or her lawyer disqualified, should also be respected. Even the appearance of impropriety concern should not extend beyond taking a private party's side on a particular matter that was the same as or substantially related to one on which the employee worked while in government.

3. Contacts or Clout. Recently the inost doininant concern arising froin the revolving door plenounenon has been the excessive influence of former officials-what in the vernacular is called "clout." The 1979 amendinents to section 207 focused on the evil thought to be posed by former employees who were believed to be highly influential within an agency by reason of their personality, knowledge, or contacts. ${ }^{205}$

It is intriguing that no private firm seems to make these assumptions about its einployees. That is, if a General Motors officer or employee takes a job with a General Motors supplier, General Motors does not refuse to deal with the supplier out of fear that its remaining einployees will not defend General Motors' interest. One might ask, then, why the government should expect less of its employees. One answer nay be that, particularly after Watergate, the public is unusually suspicious and concerned about its leaders. This concern nay go deeper than Watergate, however, and reflcct public knowledge that governmental decisions are frequently important and yet fundamentally arbitrary. Even techincal decisions often rest on personal judginents. The decision whether a given contractor is "responsible," for exainple, will never be wholly free from the judgment of responsible contracting officials. Even choosing winners of research grants involves subjective judgenent of very specific criteria. The wisdoun of dropping a charge or settling a lawsuit can rarely be reviewed on the merits. Because of the impossibility of judging tle ultimate wisdoin of some decisions, the structure of the decisionmaking process becomes even more significant.

Once again, however, this idea must not be extended too far. Influence takes inany forms. Much of what appears to be an employee's

205. See, e.g., S. Doc. No. 25 at 68 ("concern that former officials may have and exert special influence over agency personnel"); GAO REPORT 2 ("informal contacts with former colleagues still at the agency"); COMMON CAUSE STUDY 52-53 (abihity to hire former officials perpetuates "undue industry influence in federal agencies"); Tentative Draft Opinion, supra note 200, at 41. 
influence inay actually be the power or authority of his or her position, power that evaporates quickly upon departure froin government. Other people are influential, not so inuch for the job they once held, but for the next job they may hold. That is, some former officials are influential because they still have political connections and may return to another government position. Even if one were critical of that type of influence, restrictions oriented toward the former government position would be an odd way of dealing with it.

Still other influence is based on the former official's fame. Henry Kissinger, for example, could probably get through on the teleplione to inost current government officials-whetler or not in the foreign policy field-because they would be flattered or curious that lie called. But Johnny Carson or Raquel Welcli could probably get througli equally well. The point is that name recognition, as a form of influence, may be associated witl government service, but it is neither limited to sucl service nor readily amenable to rules related to former officials generally.

Most commonly, clout is viewed in terms of the former employee's personal friendships with people still at the agency. This arguinent, of course, tends to demean all federal employees. The idea that present officials make significant decisions based on friendship rather than on the inerits says more about the present officials than about their former coworker friends. It implies a lack of will or talent, or botli, in federal officials that does not seem justified or intended, and it ignores the possibility that the officials will tend to disfavor their friends in order to avoid even the appearance of favoritism. Furtler, contacts witlim an agency are not the only way people in government positions form friendships. In addition to neighbors and classmates, people also form friendships in professional organizations and even in adversarial situations. Employment contacts are only part of the friendship problem, if such a problem exists.

4. Unfair Advantage. Another complaint is that government service gives some people an inherent and unfair advantage over otliers. $^{206}$ For example, a lawyer who lias recently worked for the Federal Trade Commission may be considered better able to represent clients with trade regulation problems than someone witliout such

206. This is the centerpiece in the proposed revision of 16 C.F.R. $\S 4.1$ (b) (1980) (section 4.1(b) of the Federal Trade Commission Rules of Conduct). See also S. Doc. No. 25 at 68 ("information, influence and access . . . [1nay be used] to improper or unfair advantage"); GAO REPORT 2 ("undue industry advantage ... due to the former employee's knowledge of agency procedures and the decisionmaking process"). 
experience. If the objection is that the advantage is unfair to the government, then it is little more than a restatement of the previous three objections. If, on the other hand, the argument is that former government officials will prove more attractive to clients or employees than is "fair" to their contemporaries without a government background, then the argument is really a call for economic protection of existing firms or individuals.

To the extent that this argument is a serious objection to general experience and understanding, every person has an "unfair advantage" over every other person because of his or lier unique experiences. Persons who went to the Harvard Law School have an advantage over those who attended other schools for sone kinds of jobs im some locations. Persons who attend state law schools frequently have a similar advantage over others, including Harvard graduates, for employnient and even "influence" im certani other locations. In an efficient economic system, the individual's conparative advantage is put to best use by consumers of the services offered. It is usually cheaper for the client and more efficient for society if the person hired knows the government agency and can perform a service without first having to beconie educated about the subject. Of course, to the extent that real confidences (or impermissible contacts) are involved, then the "unfair advantage" concern should be recognized as a part of those objections. It does not, lowever, seen to be an objection that should have much independent significance.

5. Conflict of Loyalties. Another concern, also rooted in legal ethics, is that a government employee might be subject to a conflict of loyalties while still in government service. ${ }^{207}$ For example, a lawyer who plans to work for the company that he or she is currently charged with prosecuting might be teinpted to prosecute less vigorously or to allow error into the trial record in order to allow attack of the judgment on appeal. Similarly, a contracting official might award a contract to the future source of his or her inconie, or a person seeking an academic job might overlook the weaknesses in a university's accountimg for government funds.

207. This was of particular concern to the Association of the Bar Committee in 1960: "[T] he greatest public risks arising froin post-eınployınent conduct may well occur during the period of government employment, through the dampening of aggressive administration of government policies." BAR REPORT 234. See also GAO REPORT 1 ("vested interest in acting favorably toward certain companies while with an agency"); id. 2 ("appear that the einployee . . . is being rewarded for his participation while regulating the industry"); COMMON CAUSE STUDY 52 ("Those who anticipate future employinent . . . have a vested interest in acting in behalf of certain companies while in office, or at least in behalf of the industry in general"). 
This concern about conflicts of interest while an official is employed by the government seems more legitimate than the concerns previously described. Furthermore, this is the only concern that is consistent with traditional notions of conflicts of interest: it is a fear that decisions made now will be influenced by the personal interests of the decisionmaker. However, this conflict of loyalties issue is itself more complex than first appears.

Government employees, except perhaps those who entered the government immediately upon graduation from school, also have former private employers. When those firms have dealings with the government, it may be convenient to screen the former employees from those dealings. Sometimes, however, screening will not be convenient. In those cases, the government must recognize that the risk of disloyalty is not great enough to justify impeding the agency's ability to act efficiently.

Likewise, because of the skills developed and the experience gained, a person ending a government career is likely to be employed by a firm that deals with the government. Thus, the risk that a present decision will affect a future employer is inherent in acting as a governinent official. Further, because job negotiations inevitably precede hir$\mathrm{mg}$, the possibility of affecting a firm with which one is negotiating may be to soine extent unavoidable. Disqualification from acting in such situations is the obvious solution in many cases. ${ }^{208}$ Again, however, the costs of such disqualification may in some cases be greater than the benefits.

Further, the concern about dishonesty. and disloyalty is probably excessive. It is hard to imagine that a private firm would feel secure hiring solneone who had just been disloyal to his or her last client-the government. Interviews with lawyers consistently confirm that law firms want the "best" government lawyers-the ones who were hardest to beat-not the least qualified or least vigorous advocates. ${ }^{209}$ Government employees probably sense this. Viewed in this light, the conflict of loyalties concern, while not necessarily eliminated, seems less significant.

\section{Imputed Knowledge of Partners and Associates. Finally, even}

208. This, of course, is the requirement of section 208, unless the employee gets a waiver from the "Governmeut official responsible for appointment to his position." 18 U.S.C.A. § 208(b) (West Supp. 1979).

209. See Wiley, Speaking Out Against Ethics Committee Inquiry 19, District LAw., Winter 1976, at 37. The counter argument is that in doing so, the law firms are "buying the [government's] best people." Tentative Draft Opinion, supra note 200 , at 41 . 
if former government employees avoid direct personal association with cases or issues involving their former agencies, the danger exists that they could act indirectly through their partners and associates. Consequently, some have argued that the disqualification of the former official should extend to law partners or business associates. Again, the argument is derived from primciples of legal ethics. Traditionally, the actual knowledge of an attorney was attributed by agency principles to the lawyer's partners. ${ }^{210}$ Recently, the rule has been expanded to associates of the attorney; the rationale for this extension was the relatively open access to case files prevailing im law firms. ${ }^{211}$ The basic rule is stated in Disciplinary Rule 5-105(D) of the American Bar Association Code: "If a lawyer is required to decline employment or to withdraw froin employment under a Disciplinary Rule, no partner, or associate, or any other lawyer affiliated with him or his firm, may accept or continue such employment."'212 Both traditional case law and the American Bar Association Code require disqualification regardless of whether the firm "walls off" the attorney from participation in the case and excludes him or her from legal fees derived from it.213

210. See also Westinghouse Elec. Corp. v. Kerr-McGee Corp., 580 F.2d 1311, 1316-18 (7th Cir.), cert. denied, 439 U.S. 955 (1978); Laskey Bros. v. Warner Bros. Pictures, Inc., 224 F.2d 824, 826-27 (2d Cir. 1955); Note, Attorney's Conflict of Interests: Representation of Interest Adverse to that of Former Client, 55 B.U.L. REv. 61, 70-71 (1975); Note, Unchanging Rules in Changing Times: The Canons of Ethics and Intra-Firm Conficts of Interest, 73 YALE L.J. 1058, 1059-64 (1964).

211. See Consolidated Theatres v. Warner Bros. Circuit Management Corp., 216 F.2d 920, 927 (2d Cir. 1954). In that case an attorney was disqualified after he moved from the defendant's firm to the plaintiff's firm. The court dismissed his assertion that he had been "a mere law clerk" at the first firm, noting that lie liad lad access to the files and liad performed other services that "might well have" exposed him to confidential information. Id.

212. ABA CODE DR 5-105(D).

213. Id.; see Schloetter v. Railoc of Ind., Inc., 546 F.2d 706, 710 (7th Cir. 1976); Fund of Funds, Ltd. v. Arthur Andersen \& Co., 435 F. Supp. 84, 96 (S.D.N.Y.), aff $d$ in part and rev'd in part, 567 F.2d 225 (2d Cir. 1977).

In some cases, however, the courts seem willing to modify the rigid traditional rules to deal with the realities of law practice by large firms. In Silver Chrysler Plymouth, Inc. v. Chrysler Motors Corp., 518 F.2d 751 (2d Cir. 1975), one of the plamtiff's attorneys, Dale Schreiber, had worked for an eighty-person firm for three years following his graduation from law school. That firm was general counsel to Chrysler and was representing Chrysler in the suit filed by plaintiff Silver. Schreiber had worked on various Chrysler matters while an associate in the large firm, but lie liad not been involved in the suit filed by Silver or $\mathrm{m}$ any case substantially related to that suit.

The court acknowledged that disqualification is appropriate when an attorney may use confidential client information against that client. However, contrary to the usual rule, it found that the inference that any attorney received confidential client information from former law associates would be rebuttable. It was imiportant, the court argued, that the law "not unnecessarily [constrict] the careers of lawyers who started their practice of law at large firms simply on the basis of their former association. . . ." Id at 754. The court found the relevant distinction to be between lawyers heavily involved in a matter and those "who enter briefly on the periphery for a limited and specific purpose relating solely to legal questions. ... Under the latter circumstances the 
Whether these rules permit a waiver of this disqualification is not entirely clear. ${ }^{214}$ The applicable American Bar Association Code provision is Disciplinary Rule 4-101(C)(1), which allows a lawyer to "reveal: . . . Confidences or secrets witl the consent of the client or clients affected, but only after a full disclosure to them."215 If a lawyer seeks to represent a new client in a suit against a former private client, he needs the former client's consent after full disclosure. Full disclosure would arguably require the attorney to advise the former client of the seriousness of the consequences of his taking the present case. That advice could be self-serving, however, and indeed it might compromise the interests of the present or proposed client if the attorney has to explain to the potential defendant the details of the proposed represen-

attorney's role cannot be considered 'representation' . . . so as to require disqualification." Id. at 756-57. The court stated:

[No client] of a law firm can reasonably expect to foreclose either all lawyers formerly at the firm or even those who have represented it on unrelated matters from subsequently representing an opposing party. Although Canon 9 dictates that doubt should be resolved in favor of disqualification . . . it is not intended completely to override the delicate balance created by Canon 4 and the decisions thereunder.

Id. at 757 (citation omitted). In the Seventh Circuit, ou the other liand, such a "realistic" approach to disqualification has been rejected. Westinghouse Elec. Corp. v. Kerr-McGee Corp., 580 F.2d 1311, 1318 (7th Cir.), cert. denied, 439 U.S. 955 (1978) ("The district court also erroneously permitted itself to be influenced by the size of the law firm involved").

Whether two lawyers are actually members of, or affiliated with, the same firm is not always clear. This problem is best illustrated by Aunerican Can Co. v. Citrus Feed Co., 436 F.2d 1125 (5th Cir. 1971). In that case, plaintiff American Can was represented by both a national law firm and locally retained counsel in a suit to collect a judgment against Citrus Feed Co. One of the local firm's partners was at the same time representing Citrus Feed in a tax matter. The district court held that the tax attorney's actual knowledge of Citrus Feed's confidences disqualified his firm from participating in the collection action, and that the local firm's knowledge was then imputed to the national firm, thereby disqualifying it from representing American Can.

The Fifth Circuit reversed as to the national firm. (The local firm had previously withdrawn froin the case). The court noted that there was no proof that the confidential disclosures in the tax matter were substantially related to the collection matter, but the decision did not rest only on that ground. While acknowledging the importance of safeguarding attorney-client confidences, the court held that ethical primciples did not require disqualification of the national firm. The court expressed concern that double imputation of knowledge would lead to "consequent disqualification . . . ad infinitum." Id at 1129. Although the two firms had acted together, the court stressed that no employer-employee relationship existed between them. Rather, American Can had einployed and paid both. The court found that the two firms were not "associated" simply by having this common client.

214. Under the ABA Code of Professional Responsibility, mere waiver is not enough. A lawyer may represent two clients only "if it is obvious that he can adequately represent the interest of each." ABA CODE DR 5-105(C). Of course, DR 5-105(C) could not hiterally apply to the revolving door situation because it only relates to the waiver of a conflict between two present clients. The importance of the language for our purposes, however, is that it does not allow the clients to waive disqualification in all cases; it requires the attorney to make a judgment of his own. It is only aftcr the attorney is himself satisfied that his independent judgment will not be compromised that the issue of waiver even arises.

215. ABA CODE DR 4-101(C)(2). 
tation. Further, the former client has no obvious incentive to give his consent. Almost certainly, the former client will be worse off if the former lawyer takes the case than if the potential plaintiff has to find and pay to educate someone new. It seems unreasonable, then, to expect that the withholding of consent by a former client-private party or government agency-will be a valid indication that disqualification is really necessary.

Recognizing that an entire firm should not necessarily be disqualified because a former client refuses consent, many observers have concluded that the primciple of Disciplinary Rule 5-105(D) should not be extended to government employees. The proposals of the American Bar Association, the Association of the Bar of the City of New York, and the District of Columbia all concurred with this position. ${ }^{216}$ The Court of Claims, as well, in Kesselhaut. v. United States, ${ }^{217}$ recognized the impropriety of disqualifying an entire firm when screening procedures would be effective.

Should an attorney ... ineluctably infect all the members of any firm he jomed with all his own personal disqualifications, he would take on the status of a Typhoid Mary, and be reduced to sole practice under the most unfavorable conditions. ... [T] he withholding of consent by the Government, as here, [should not] be binding on us if, as here, it appears now to be unjustified.218

Kesselhaut was not the last word. As previously discussed, ${ }^{219}$ the Second Circuit in Armstrong v. McAlpin ${ }^{220}$ adopted a rule barring the entire firm-at least whenever a partner or associate had been personally and substantially involved im a matter while in government employment-because "it must appear to the public, that there will be no possibility of financial reward if [the employee] succumbs to the temptation to shape the government action in the hope of enhancing private employment."221

Any opinion such as that of the Second Circuit that is based on the appearance of impropriety is extraordinarily difficult to analyze. That such an appearance may exist to the judges deciding the case is a point that no observer can challenge. However, one can ask whether such an

216. See notes 80, 89-94 supra and accompanying text. The Senate Government Operations Committee agreed with the ABA position, see S. Doc. No. 25 at 87 , and the approach was also adopted by the Office of Personnel Management in 5 C.F.R. $\S 737.21(\mathrm{~b})$ (1979).

217. 555 F.2d 791 (Ct. Cl. 1977).

218. Id at 793-94. On the other hand, eight of the nineteen inembers of the D.C. Bar Ethics Committee beheved no waiver should be permitted at all. D.C. Bar Proposals 48.

219. See notes 132-44 supra and accompanying text.

220. 606 F.2d 28 (2d Cir. 1979), rehearing en banc granted, No. 79-7042 (2d Cir. Dec. 12, 1979).

221. 606 F.2d at 34 
appearance is reasonable and in this case it seems clear the court should have reached a different result.

First, the saine factors that convinced the court that there was no actual impropriety could have led just as easily to the conclusion that there was no appearance of impropriety. The law firm was retained six months after its new associate, Altman, had left the government, and it was retamed by the receiver with full knowledge that Altman could not play any role $\mathrm{m}$ the matter. The receiver who hired the law firm had been named well over a year before Altman left the government, and there was at least no overt suggestion that Altman had had any role in the selection of that receiver.

Second, the court rested its decision in part on the premise that Altman might have seemed tempted to work less vigorously for the government because he wanted a job with this private firm. ${ }^{222}$ However, even assuming a firm would hire him on this basis, ${ }^{223}$ the interest of the private firm and its client were consistent with that of the government. Because there was no confidentiality issue involved, it is difficult to understand what Altman could have done that would have actually or apparently compromised his work for the Securities and Exchange Commission.

Third, it seems mappropriate to allow a private litigant to raise an objection that purports to protect ouly the interest of the government. There is no suggestion that Altman would be able to use contacts he had at the Securities and Exchange Commission to abuse McAlpin's rights. Instead, the Second Circuit relied on a government imterest that was already redressable by the government under section 208,224 and created a remedy that does little more than make it more time-consuming and expensive for the plaimtiff to pursue his private action agamst someone the government has already determined to be a wrongdoer.

In sum, the Court of Appeals for the Second Circuit in Armstrong, in its concern about the possibility of impropriety, established a rule whose arbitrary application seems likely to create significantly more costs for litigants, imcluding the government, than benefits. The position taken by the Court of Claims in Kesselhaut, ${ }^{225}$ the Fifth Circuit in Woods v. Covington County Bank, ${ }^{226}$ and all of the bar associations that

222. Id. at 32-33.

223. See note 209 supra and accompanying text.

224. Section 208 prohibits a government employee from participating in any inatter in which his future employer has a financial interest. See text accompanying note 55 supra.

225. See notes 217-18 supra and accompanying text.

226. 537 F.2d 804 (5th Cir. 1976). See note 204 supra and accoinpanying text. 
have considered the question ${ }^{227}$ seems clearly preferable.

\section{Costs Imposed By An Overly Restrictive Rule.}

Although none of the six bases used here for restricting the private activities of former government employees should be discounted completely, the apparent significance of each seems to fade rapidly upon analysis. A further consideration in creating these revolving door rules is the costs created by an overly restrictive approach. One of the problems in analyzing the revolving door issue has been that the rules frequently have been drafted by lawyers to address lawyers' probleins. Even in our regulated society, the majority of government employees are nonlawyers, and the rules fail to accommodate the problems faced by these nonlawyers.

Contracting officials, for exainple, are often a crucial interface between the private sector and the government. The government official distributing grants for cancer research and the private researcher are not opponents. They both have the same motiviation: to conquer cancer. In this sense, there is no analogy to the lawyer who moves from one chient to another. On the other hand, in the award and funding of cancer research contracts, the private contractor (whether or not nominally a not-for-profit institution) may be expected to want an increase in the funds available for the work, while to some extent, it will be in the government's interest to constrain the level of funding. ${ }^{228}$ The contracting area, then, is a peculiar coinbination of teainwork and conflict, but in very few senses is it amenable to rules developed for lawyers.

Further, even to the extent that the lawyer analogy is helpful, the assumption that rules relating to private lawyers can be transposed to the government setting is questionable. For example, there is an extensive body of case law concerning the private lawyer's obligation not to take a case contrary to the interest of a former private chent, at least when to do so might abuse the confidences and secrets of that private client. ${ }^{229}$ Such a rule is understandable and miposes relatively few costs on the private sector. If one law firm is obliged to turu down a case under the rule, many other firms are available. In general, the number of such cases is likely to be relatively small and of relatively little consequence to any given firm. The government, on the other

227. See note 216 supra and accompanying text.

228. The 1979 changes to section 207 essentially eliminate the barriers to university officials moving from federal jobs to nonprofit or university positions administering contracts they granted. This analysis suggests that "not-for-profit" organizations nuay in fact prcsent many of the same concerns that Congress was worried about.

229. See authorities cited in note 210 supra. 
hand, preempts many fields. If a tax lawyer were barred from all tax cases because he or she had worked on regulations for the Internal Revenue Service, the sanction would not be the denial of a few cases; it would be the inability to practice the profession for the prescribed period. In addition, the government obviously employs inany times inore people than any individual firm. Thus, the consequences of any of its rules are substantially inore widespread and pervasive. Neither of these observations demonstrates that the private lawyer analogy is never useful. They do suggest, however, that an assessment of the appropriate rules to be ultimately adopted must also take into account the countervailing costs created by an overly restrictive policy.

The Congressional Budget Office estimated that the cost of the 1978 amendinents to section 207 was zero. ${ }^{230}$ As an estimate of budget impact, that was perhaps optimistic; as an estimate of social cost, it was clearly wrong. Unfortunately, no reahistic estimate of social impact has even been attempted, but an understanding that there is such an impact is essential. The social costs take at least four forms: problems created for government recruitment, inhibitions on the independence and creativity of persons in government service, a reduction in freedon1 of choice for former employees and the persons consulting them, and a loss to society through a balkanization of government service and thus a lessening of the perception of public service as a desirable part of a broad career.

1. Problems for Government Recruitment. "To make government service inore difficult to exit can only nnake it less appealing to enter."231 A professional person usually has only one commodity for sale-his or her skill and judgment. Economists call this "human capital," and one of its primary coinponents is experience. The fact that an attorney worked on the assembly line of an automobile coinpany while in law school, for example, inay give him or her unusual imsights into the way cars are inade. Indeed, any individual builds up a store of experiences and information during a lifetime, and it makes economic sense, for both the individual and the economy, for that human capital to be expended in the most effective way.

Human capital is not only of great personal value to the professional; it is, taken collectively, a national asset. Government employees develop experience and understanding during their periods of service

230. H.R. REP. No. 170, supra note 116, at 162-63.

231. Remarks of Federal Trade Commission Chairman Calvin Collier before Council on Younger Lawyers, 1976 Annual Convention of the Federal Bar Association (Sept. 16, 1976), quoted in S. Doc. No. 25 at 65. 
that later make them valuable to private clients. These insights and experiences are often unavailable in the private sector except from other former government employees, and, if private chents cannot call upon these former officials, they may get poor advice or unore expensive advice, or both. Rehance on this experience in the private sector is no inore inappropriate than is the former auto worker's handling a case agaimst an auto company.

Depreciating the value of the human capital that a government employee accumulates will discourage people from seeking government employment. Although individuals do not enter government service solely to have something to sell when they leave, as individuals evaluate careers and consider whether to accept a government position, they see the ability to gain experiences they can use later as a part of the compensation for the position. Restraints placed upon their subsequent employinent will reduce this apparent compensation, and eventually will affect the number and type of people willing to enter government service.

It is useful to break down professional life into at least three periods. First, most professions have an apprenticeship phase lastimg from five to ten years. During that period, the individual does some professional work, but an equally important aspect of this period is gaining experience that allows him or her to move on to the next stage. The next stage, also generally lasting about ten years, is the "jumior partner" level. At this stage more imdependence is possible, and during this period most people achieve the levels within their profession that they are likely to sustain throughout their careers. The third and longest phase is one in which individuals continue working at their careers, but frequently supervise others and act in a managerial or "senior partner" capacity.

These distinctions are important because the government needs people at all three levels. Although imdividuals pass through all three stages within the government, even those who make the government a "career" usually do not commit their entire professional lives to government service. Instead, they retire after twenty-five to thirty years and have a significant number of productive years remaining.

As the rules on postemployment activities become more restrictive, it mevitably will be more difficult to get people to accept government positions durmg one or more of these phases of their careers. Suppose two students graduate from law school in the same year. One goes to a law firm and the other to the Federal Trade Commission. After five years, the private lawyer may expect to be close to a partnership im his firm, having been educated in that firm's procedures and in the sub- 
stantive problem areas in which he will concentrate. The Federal Trade Commission attorney, with no position in a private firm, will only have received experience that might make her equally attractive to private clients. If that experience is deemed comparable by the job market, then her time with the agency will have been well spent. However, if the experience that she has obtamed may not be used in her subsequent career, then her time in government service nay well have been wasted. Indeed, if she is prohibited as a private attorney from working on cases involving the government, then her period of government service will have been a significant detriment to her career. One does not have to be committed to the view that all human decisions are economically motivated to see that, if postemployment activity is more severely restricted, the experience gamed in government service will become less valuable and, therefore, such service will become less attractive.

Perhaps even more significant is the probable effect on the recruiting of senior people for short-term government service. People in the second and third phases, the junior partner and senior partner levels, are likely to be earning large inconies. They must make significant financial sacrifices in order to take government positions. Consider a person making $\$ 120,000$ a year in securities law, for exanple, who is offered a seat on the Securities and Exchange Commission paying $\$ 60,000$. If the $\$ 60,000$ annual sacrifice is conipounded by the knowledge that his practice of securities law will be restricted when he returns to private life, he niay conclude that the sacrifice is too great.

The number of desirable public servants who would accept government employment but for posteniployment restrictions is unknown. The Carter Admimistration reportedly found that no one declined.a Cabimet position for the stated reason that he or she wonld not be willing to conıply with posteniployment restrictions. ${ }^{232}$ However, the experience of recruitimg individuals for highly prestigious, visible positions is not necessarily analogous to the experience of recruiting for thousands of other responsible but less glaniorous government positions. ${ }^{233}$

2. Effects on Official Independence. The second and less fre-

232. For commitments made by the appointees, see 35 CONG. Q. WEEKLY REP. 56-57 (Jan. 8, 1977).

233. At one point in the debate over the District of Columbia Bar proposals, the chief legal officers of nine Cabinet departments objected to the effects the proposals would have on recruitment. Bar's "Revolving" Door Plan Attacked, Washington Post, Oct. 10, 1978, § A, at 3, col. 3. See also Internal Revenne Service Chief Connsel's Advisory Committee on Rules of Professional Conduct, 41 Fed. Reg. 41,106, 41,113 (1976). 
quently discussed cost of restrictions on postemployment activities is their potential impact on employees' freedom and flexibility while im government. As one interviewee said, "A bureaucracy is only as good as the market value of the bureaucrats on the outside." An individual who has the security of knowing he or she can find private employment upon leaving the government is free to work vigorously, challenge official positions when he or she beheves them to be $\mathrm{m}$ error, and resist illegal demands by superiors. An employee who lacks this assurance of private employment does not enjoy such freedom.

By unfortunate coincidence, Congress adopted federal civil service reform measures at the same time that it tightened restrictions on postemployment activity. According to the Civil Service Reform Act of 1978,234 certam federal officials in grades GS-16, GS-17, and GS-18, or Levels IV and V of the Executive Salary Schedule are eligible for the Semior Executive Service. While these senior executives are afforded substantial civil service protection, a system of performance ratings, incentive pay, and nonconsensual reassignments was established that considerably increased the power of top-level agency administrators. ${ }^{235}$ The object of these changes was to establish in the administration of government agencies some of the standards of performance accountability utilized by private busmess. That, in itself, is not objectionable. However, government's postemployment restrictions lave no private analogy. Thus, the combined effect of the new laws does not create a situation of comparability with private busmess, but rather a situation in which senior government executives are substantially more locked in and dependent upon their superiors' rating. The restraints thus imposed on independence and honesty in government service may be significant. Any system that affects the right to take a new job affects the ability to quit the old job, and any limit on the ability to quit inhibits official independence.

\section{The Effect on Personal Freedom of Employees and Those Who} Employ Them. Typically, cost-benefit analysis focuses primarily on costs that can be expressed in dollars or in losses of government efficiency. That is understandable, given the way most cost-benefit issues are posed, but in a free society some otlier costs are also relevant.

234. Pub. L. No. 95-454, 91 Stat. 111 (codified in scattered sections of 5 U.S.C.A. (West Supp. 1979)).

235. The relevant provisions may be found at 5 U.S.C.A. $\$ \$ 3391-3397$ (West Supp. 1979) (appointment, reassignment transfer, and development); 5 U.S.C.A. \$\$ 3591-3595 (West Supp. 1979) (removal, reinstatement, and guaranteed placement); 5 U.S.C.A. $\$ \S 4311-4315$ (West Supp. 1979) (performance appraisal); 5 U.S.C.A. $\$ 4507$ (West Supp. 1979) (awarding of ranks); and 5 U.S.C.A. $\S \S 5381-5385$ (West Supp. 1979) (pay). 
Many individuals, while not wishing to work permanently for the government, would like to spend soine time in public service. Restrictions that deter these persons from fulfilling their desire for government positions represent a significant cost affecting the freedom of those individuals to plan their careers.

Similarly, these restrictions impose costs on potential employers of the former government official. A university that cannot hire an experienced government research scientist must hire someone less experienced. A client who calmot hire a lawyer experienced in commodities law inust, in effect, pay to educate a lawyer less experienced. A company that cannot rehire its vice-president because he or she worked as a presidential appoimtee has lost a major investment in that man or woinan. Although these illustrations suggest a less fundannental loss of personal freedom than the exaunples involving employees, losses to potential employers can be real and significant.

4. Dangers of Creating a Class of Professional Civil Servants. The final cost follows from the first three. As the "door" is constrained from "revolving," fewer people will pass through it. The result will be a more complete separation of government lawyers from those who engage in private practice. At a minimum, it will tend to make the academic community the only source of persons free to take relatively short-term government positions.

Such a result creates at least three problems. First, government will be denied the influx of views from outside the government. It is one thing to hear the view that the agency's policies need change expressed by advocates; it is quite another to have to deal with insiders who want change. Barriers to government service entry created by severe probleins upon exit will likely lead to more rigid attitudes within the agencies and tend to create a Mandarin class less consistent with the democratic ideal.

Second, such barriers often block those who could receive the most benefit from government experience. Among the opponents of revolving door limitations have been minority groups who have seen government service as an important route to private sector jobs. ${ }^{236}$ Black law students, for example, have avoided discrimination by taking federal positions and then used their experience and demonstrated skill to secure jobs in law firms that might otherwise have been reluctant to hire them. It is not only the wealthy and powerful that move through the

236. E.g., Comments of the Washington Bar Association before the District of Columbia Court of Appeals in connection with the proposed amendment to Canon 9 and ancillary annendinents to its Disciplinary Rules (July 9, 1979). 
revolving door.

Third, on a practical level, the interchange of persons often works directly in the government's interest. Government alumni often help comnunicate policies and attitudes of their agencies better than books or speeches. After retiring to a private role, the foriner government official nnay retain soine of the attitudes and insights acquired while in government. A former Justice Department or Securities and Exchange lawyer inay set a tougher coinpliance program for his or her client thar. a nonalumnus of those agencies.237 Because former alumni of an agency inay prove to be soine of its best friends, the closing of the revolving door may prove inore harmful than helpful to the agency.

\section{Proposed Approach to the Problem of Deciding When Participation by a Former Agency EMPLOYEe Is INAPPROPRIATE}

\section{A. Some General Concerns.}

This Article has suggested that-because rules may limit the attractiveness of government positions and inay reduce einployee creativity in those positions-individuals, government, and the public all have soinething to lose from the imposition of arbitrary rules upon the activities of former government einployees. The rules, therefore, should be tailored to limit only those situations that pose problems of real abuse of the public trust. In most cases, theoretically and practically, the foriner government einployee should be afforded the opportumity to develop and exploit his or her "human capital."

In addition, the rules should be explicit, an objective not met by section 207. Several interviewees echoed the observation made by Judge Kaufinan over twenty years ago that an accusation of unethical conduct can be as serious to a person's carcer as a conviction of misconduct. ${ }^{238}$ If rules are vague or if regulations are necessary to ensure that certain activities are permissible, the risks of being exposed to possible press or public allegations of violations inay be too great for many people to assume. Inevitably, complex probleins do not admit of easy solutions, but clarity and certainty as to what the apphicable rules require in a given case seein essential objectives.

\section{B. The Analytical Questions Revisited.}

1. The Role of the Employee While in Government. First, it seems that law should draw distinctions based on the naturc of the govern-

237. See GAO REPORT 2.

238. See notes $36-40$ supra and accompanying text. 
ment job. Technical personnel who provide information in a common undertaking with the government present problems different from those raised by persons who negotiate the financial or other relationships between the government and private sector firms. Lawyers should not be distinguished from contract negotiators and administrators, for example, but these persons should be distinguished froin researchers whose private work can be almost identical to the work they were doing for the government.

The distimction between personal involveinent and official responsibility does seem to be an important one. Indeed, the concept of offcial responsibility pertains to little of real substance. An official cannot know confidences about matters in which he or she was not involved, nor can he or she abuse the government's interest regarding decisions that were not his or hers to make. Likewise, whether or not a matter was within one's official responsibility has little impact on a person's actual influence. In this respect, the approach taken by the American Bar Association Code of Professional Responsibility is better than that taken in the federal statute.

The "official responsibility" concept was a reaction of the Association of the Bar report in 1960 against the Standard Oil decision. ${ }^{239}$ It went too far. Interestingly enough, none of the imterviewees contacted in the course of this study seeined troubled at being excluded from matters within their official responsibility. Ideally, however, if one were rewriting the law and regulations, one should make disqualifymg only those matters in which the individual was personally involved.

For the same reasons, the employee's salary level or job title should not be a basis for imposing restrictions. These factors do not necessarily determine the specific types of decisions or information for which the employee is responsible. Moreover, the cost of such rules is extremely high, because they affect people being recruited for the hardto-fill jobs in the senior ranks of the civil service and the less visible executive level appointments-people who are likely to refuse government service out of concern about these restrictions - rather than affecting the high-level presidential appointees. ${ }^{240}$

2. The Lawyer's Role in Private Life. Turning to the official's role after leaving government service, the distinction between personally appearing before an agency and privately advising a client is more complex than it may seem. Participants in the congressional deliberations apparently assumed that influence was the only major concern of

239. See notes 50-53 supra and accompanying text.

240. See notes 232-33 supra and accoinpanying text. 
the statute, and, therefore, that personal intervention should be the only matter of concern. ${ }^{241}$ On the other hand, if the abuse of confidential information or msights is also a concern, then private advice would be at least as serious an evil as personal appearance. As argued earlier, it does not seem that either concern is likely to present a serious problem in most cases. Further, agencies vary in the extent of their truly confidential information and the extent of their relatively unreviewable or "arbitrary" discretion. Thus, it seems that the issue of barring personal intervention or private advice, or both, is appropriate for individual agency regulation subject to the approval of the Office of Government Ethics.

The distinction between a former employee seeking information and one pleading a cause is also often far from clear. Judicious questions will often move a matter ahead in the agency decisionmaking process, a result that may be as effective as any advocacy. Abuse of confidential information could occur in either role, but possession of improper influence is less dangerous in the information-seeking role than in the advocate role. Thus, the provision in section 207242 limitimg the prohibition on high level employees to actual attempts to influence the former agency, while broadening the prohibition on persons with substantial personal involvement, seems the sensible approach.

On the other hand, distimctions should be made on the basis of whether the private role is related to a specific case the person handled, a later similar case, or a later rulemaking proceeding. The first should be highly restricted, while the last two require very little or no restriction. In a rulemaking proceeding, the range of interests expressed is normally so great and the questions are usually at such a high level of policy that no one individual could distort the results. Likewise, while later similar but unrelated cases may be the subject of less public attention, only the concern about undue influence could have any validity. Only in cases or projects actually liandled by the employee could the abuses of botl confidential information and undue imfiuence pose a threat. Thus, the approacl taken by the American Bar Association Code and the federal statutes seeins far superior to that of the proposed District of Columbia Bar rules. ${ }^{243}$

The bar to postemployment activity certainly should not be extended beyond the employee's former agency. Indeed, the authority in section 207 to limit the bar ouly to actions before a part of the former

241. See, e.g., S. Doc. No. 127 at 73-77.

242. 18 U.S.C.A. $\S 207$ (West Supp. 1979), as amended by Pub. L. No. 96-28, 93 Stat. 76 (1979).

243. See notes 172-73 supra and accompanying text. 
employee's agency or department should be retained. Of course, the prestige that an individual has at a given departinent inay extend to other government agencies, so that if prestige is to be condemned, agency boundaries have hittle ineaning. However, because postemployment restrictions inust end at soine point, the lines drawn im section 207(c) seem a reasonable compromise.

The government clearly should be imterested in the conduct of employees in job negotiations before leaving government service. However, it is particularly difficult to formulate specific rules to regulate this conduct without excessively restricting the government official's ability both to handle day-to-day busmess and to establish a smooth transition to private life. Perhaps the best solution would be to require the individual to inform his or her agency superiors of any job negotiations that might affect his public responsibilities. If possible and consistent with the government's needs, he or she could be removed from cases involving those firms. If, from the government's position, it is not convenient to remove the official, then he or she should not be barred from such dealings. A record should be inade of any such incident and filed with the Office of Government Ethics both to verify that the employee openly reported his or her actions and to docuunent why he or she was not removed from the dealings. ${ }^{244}$

Finally, prohibition of conduct consistent with the government's interest may seen one of the subjects of least concern, but further reflection suggests that it unay be one of the most important. For example, if the government receives confidential information froin a private firm, the government official who has had access to that information may mdeed have an unfair advantage that will be detrimental to both the private firm, which has been effectively misled, and the government, when it seeks further information. In such a case, it may be shortsighted for the government to prevent, as it does in section 207, only subsequent activity affecting the immediate interest of the government.

3. General Procedural and Enforcement Issues. The length of the bar to postemployment activity is, again, a function of the objectives to be served. In this connection a useful concept is that of the half-life, which scientists apply to atomic particles. While radioactivity lasts for a long time, half of it is dissipated within a specific, relatively short time. Similarly, influence and confidential information are wasting assets as former friends leave the agency and as new policies are formu-

244. Section 208 already requires notification by the employee. This proposal seeks to clarify how the agency is to deal with that notice. 
lated by succeeding administrations. To formulate a cooling off period for former employees, one must attempt to calculate the rate of decay of influence and confidences. That is obviously difficult to do, but the interviews done for this Article suggest that the half-life of such assets is indeed short. The one-year "cooling off period" provided now by section 207(c) is probably a realistic one. The permanent bar against participation in matters with which an individual was personally and substantially involved is derived from the traditional rule for attorneys in private cases and may be realistic im long, protracted lawsuits, but its application to the general issues of government is questionable.

The problems of attribution have been among the most difficult. The decision in Armstrong v. McAlpin ${ }^{245}$ prevents ignoring the problein any longer. Because a statute probably cannot address all possible cases, the courts should be able to require disqualification when there is some slowing of actual impropriety. However, contrary to the court's approach in McAlpin, the agency's view of when its interests need protecting slould be given significant weight in the court's decision. The position taken in American Bar Association Formal Opinion No. 342,246 therefore, seems appropriate. ${ }^{247}$

Of course, nothing is sacrosanct about the size of large Washington law firms, the chief beneficiaries of the American Bar Association's approach. Lawyers could practice in smaller organization umits, as in England. ${ }^{248}$ However, it does not seen reasonable to require, in effect, sucli smaller units through a broad attribution rule unless something affirmative is to be gained. The interviews done for this Article suggest that walling off disqualified firm members can and does work. Furthermore, a formal waiver approach does not appear desirable. ${ }^{249}$ As the court realized in Kesselhaut v. United States, ${ }^{250}$ the issue really ought not be discretionary; screening is either effective or ineffective. ${ }^{251}$ At inost, requiring a firm to file an affidavit about the screening might be necessary to assure all persons that the firm and the former official

245. 606 F.2d 28 (2d Cir. 1979), rehearing en banc granted, No. 79-7042 (2d Cir. Dec. 12, 1979). See notes 219-27 supra and accompanying text.

246. ABA OPINION, No. 342, supra note 74.

247. See notes 74-80 supra and accompanying text.

248. Barristers in England do not form any partnerships at all, largely to avoid the possibility of imputed disqualification. See generally W. Boulton, A Guide to Conduct AND ETIQueTte AT THE BAR 58-63 (6th ed. 1975).

249. See note 214 supra and accounpanying text.

250. 555 F.2d 791 (Ct. Cl. 1977). See notes 217-18 supra and accompanying text.

251. The prevention of indirect benefit to the former einployee is difficult if the employee works for a corporation, because the security of his paycheck is enhanced if the company makcs money instead of losing it. However, the concern about attribution is a traditional concern about lawyers rather than about people in business. 
recognize the obligation. The injury to reputation and the potential financial loss from a failure to screen properly are probably sufficient incentives to guarantee that the required separation will be maintained. 252

The criminal penalties for violatimg the restrictions on postemployment activity are largely archaic and should be eliminated. Criminal penalties were instituted in 1948 wlien the prohibition was still aimed at preventing fraud in tlie narrow activity of prosecuting specific claims against the government.253 However, inost of the restrictions of concern today do not involve fraud. Instead, they involve appearances or theoretical possibilities for abuse, and thus the criminal penalties have not often been enforced.254 If the statutory rules were narrowed-for exainple, if they prohibited only the switching of sides in a specific case, or the failure to screen a disqualified former official, or overt acts of favoritism to a potential future employer-then soine criminal sanction might be appropriate. For most violations, such as the appearance of impropriety, however, tlie type of administrative remedy created by the 1978 amendinents to section 207 should be the sole reinedy for enforceinent.

The revolving door turns into the government, as well as out of it, and the rules adopted should deal with both phenomena. Only the District of Columbia Bar proposal currently does so. ${ }^{255}$ As with restrictions applicable to persons leaving the government, restrictions applicable to persons entering the government should be narrowly drawn.

Congress and individual agencies, rather than bar associations, courts, or professional groups, should establish rules relating to posteinployment activity of federal officials. Whatever rules are adopted have important costs associated with them, both for the individuals involved and for the effective operation of government prograins. Thus, it is inappropriate for an outside professional association to create or impose such costs for the government. 256 As the earlier statistics showed, ${ }^{257}$ some individual agencies face unusual problems; Congress, therefore, should expressly grant agencies the authority to modify or

252. Violation of the representations in the affidavit presumably would also make at least one member of the firm guilty of perjury.

253. See notes 24-26 supra and accoinpanying text.

254. Between 1970 and 1976, the Justice Department brought five cases and obtained one conviction. GAO REPORT 9.

255. See note 184 supra.

256. This position was vigorously defended by the Departmeut of Justice in its Memorandum to the Ethics Committee of the District of Columbia Bar (Feb. 15, 1978). A copy of this menorandum is in the files of the District of Columbia Bar.

257. See notes 150-56 supra and accompanying text. 
even to go beyond the basic restrictions imposed. However, in the interest of simplicity, careful evaluation of the competing costs and benefits, and maximum practical uniformity, even agency rules should be subject to the approval of the central Office of Government Ethics.

Finally, people base decisions about their lives and careers on the types of rules discussed in this Article. Thus it seems unfair to impose any new restriction upon people who have already made such decisions. If more restrictive rules are adopted, they should be applied only to persons subsequently entering government; they should not apply to persons who have already left government or to persons currently in the government, unless a reasonable transition period is established in which people may resign if they do not wish to be bound by the restrictions. If the recommendations of this Article were adopted, of course, the new restrictions on government employees would not be as great as they are currently.

\section{Specific Proposals.}

The two years of frustrating legislation and the partial repeal of section 207258 have probably left Congress with little interest in addressing the revolving door issues again in the near future. However, the remaining controversy and counter proposals such as that of the District of Columbia Bar inake the taking of some concrete steps to simplify and clarify the law in this area seem desirable.

First, the problem of postemployinent activities of former federal employees is too coinplicated and the distimctions between permissible and impermissible conduct are too fine to be handled by a criminal statute. The current federal law ${ }^{259}$ should be replaced with a new statute providing for civil or administrative enforcement and penalties.

Second, although the concern frequently expressed about the problein of switching sides seems excessive, the present permanent bar on representation of a private party in any "particular matter involving a specific party or parties" in which the employee participated "personally and substantially" on behalf of the government ${ }^{260}$ should be retained in the new statute. However, no restriction should be placed on representation with respect to other matters, such as those that were pending under the einployee's official responsibility but in which he had no personal and substantial participation. ${ }^{261}$

258. 18 U.S.C.A. $\& 207$ (West Supp. 1979), as amended by Pub. L. No. 96-28, 93 Stat. 76 (1979).

259. Id.

260. Id. \& 207(a).

261. This concern seems exaggerated because one can be involved "personally and substan- 
The present one-year cooling off period on personal advocacy by former high-level personnel before their former agencies, set forth in section 207(c), is a reasonable compromise and should be retained. The one-year ban should only reach personal attempts to influence the agency, and not acts of aiding or advising private colleagues or clients or obtaining information from the agency.

Congress should authorize agencies to nnpose, with the concurrence of the Office of Government Ethics, additional restrictions based on their particular needs. The proposed legislation, however, should preempt the rules of professional organizations and courts dealing with the subject of postemployment restrictions.

Fimally, regardless of the action Congress takes on the above proposals, a former employee's disqualification ordmarily should not extend to his law firm or organization. Instead, Congress should bar the former employee both froin personal participation in the matter and from receiving compensation for anyone else's participation. A partner in the firm should submit an affidavit stating that the former einployee has been so screened, not as a basis for government approval, but to assure that the firm has in fact recognized the issue and taken steps to deal with it. Courts should retain authority to decide that the circumstances in a particular case require a broader disquahification. In considering whether to do so, courts should give special weight to the agency's view as to whether the screening arrangement affords adequate protection to its interests. ${ }^{262}$

tially" by signing a complaint in a case, see Telos, Inc. v. Hawaiian Tel. Co., 397 F. Supp. 1314 (D. Hawaii 1975), but unless it appears that the signer could have prevented the complaint or knows some secrets about the strength of the government's case, disqualification does not seem to serve any real governmental interest.

262. The proposals in this Article were adopted by the Administrative Conference of the Umited States as Recommendation 79-7 (Dec. 14, 1979), except that the Administrative Conference called for retaining the possibility of criminal sanctions for "clearcut and egregious violations" of section 207. 
